\title{
10. IMPLICATIONS OF SEDIMENT COMPOSITION ON THE SOUTHERN KERGUELEN PLATEAU FOR PALEOCLIMATE AND DEPOSITIONAL ENVIRONMENT'1
}

\author{
Werner U. Ehrmann²
}

\begin{abstract}
Cretaceous to Quaternary sediments recovered at Leg 119 Sites 738 and 744 on the southern tip of the Kerguelen Plateau were studied in order to determine the depositional environment and the paleoceanography of the southern Indian Ocean and especially the long-term glacial history of East Antarctica. Emphasis is given to bulk-sediment composition, grain-size data, and clay mineralogy.

The sediment sequence at the two sites is generally of a highly pelagic character, with nannofossil oozes, chalks, and limestones dominant from the Turonian to upper Miocene and diatom oozes dominant within the uppermost Miocene to Holocene interval.

The first indication of glaciation at sea level is the occurrence of isolated gravel and terrigenous sand grains, which indicate ice rafting in the middle Eocene interval of 45.0-42.3 Ma. A major intensification of glaciation, probably the onset of continental East Antarctic glaciation, is recorded in sediments of early Oligocene age (36.0 Ma). All major sediment parameters document this event. The clay mineralogy changes from smectite-dominated assemblages, typical of moderately warm and humid climatic conditions in which chemical weathering processes are prevalent, to illite- and chlorite-dominated assemblages, indicative of cooler climates and physical weathering. Ice-rafted debris of both gravel and sand size occurs in large quantities in that interval and coincides with a change in the mode of carbonate deposition. Carbonate contents are relatively high and uniform $(90 \%-95 \%)$ in strata younger than early Oligocene; in Oligocene to upper Miocene strata they fluctuate between $65 \%$ and $95 \%$.

Oligocene and Neogene hiatuses reflect an intensification of oceanic circulation and the increased erosional force of Circumpolar Deep Water. The long-term Cenozoic cooling trend was interrupted by a phase of early Miocene warming indicated by maximum Neogene smectite concentrations. Although ice-rafted debris is present only in minor amounts and mainly in the silt fraction of early Oligocene to late Miocene age, it shows that glaciers advanced to the East Antarctic shoreline throughout that time. Ice-rafting activity drastically increased in latest Miocene time, when carbonate deposition decreased and diatom ooze sedimentation started. This suggests a pronounced intensification of Antarctic glaciation combined with a northward migration of the Polar Front.
\end{abstract}

\section{INTRODUCTION}

The Southern Ocean around the Antarctic continent plays a critical role in controlling the global climate and oceanography, because the Antarctic coastal regions with their extensive ice shelves are the principal sources for southern oceanic bottom waters, which influence the hydrography of large parts of the world oceans. Changes in the plate tectonic configuration and in the intensity of glaciation in the southern high latitudes have had great impact on the development not only of regions in the Southern Hemisphere, but also of far-distant regions. Drilling in the seas around Antarctica consequently has been a main target, both during the early days of the Deep Sea Drilling Project (DSDP Legs 28, 29, 35, and 36) and recently for the Ocean Drilling Program (ODP Legs 113, 114, 119, and 120).

One of the principal objectives of Leg 119 was to study the long-term glacial history of East Antarctica and its implications for the paleoceanography and depositional environment of the southern Indian Ocean. For this purpose, two sites (736 and 737) were drilled on northern Kerguelen Plateau, two sites (738 and 744) on southern Kerguelen Plateau, two sites (745 and 746) in the Australian-Antarctic Basin, and five sites (739-743) in Prydz Bay on the East Antarctic continental shelf (Barron, Larsen, et al., 1989). The drilling results from the Prydz Bay sites,

\footnotetext{
${ }^{1}$ Barron, J., Larsen, B., et al., 1991. Proc. ODP, Sci. Results, 119: College Station, TX (Ocean Drilling Program).

2 Alfred Wegener Institute for Polar and Marine Research, Columbusstraße, D 2850 Bremerhaven, FRG.
}

which were expected to reveal the onset of continent-wide glaciation and to document in detail the Cenozoic glacial history of East Antarctica, suffered from poor recovery rates and poor stratigraphic control (Hambrey et al., 1989; this volume; Barron, Larsen, et al., 1989). Therefore, this paper concentrates on the pelagic sediments recovered at Sites 738 and 744 in the southernmost Indian Ocean (Fig. 1). The Mesozoic to Quaternary sedimentary record is investigated in order to decipher, describe, and interpret the depositional environment and to deduce information concerning the onset of glaciation and the subsequent Cenozoic glacial history of East Antarctica. Emphasis is given in this paper to bulk-sediment composition, grain-size data, and clay mineralogy.

The two investigated sites are strategically positioned for high-latitude paleoceanographic and paleoclimatic studies on the southern tip of the Kerguelen Plateau, north of the deep-water $(>3500 \mathrm{~m})$ pathway between Antarctica and the plateau. Site 738 was drilled at $62^{\circ} 42.54^{\prime} \mathrm{S}, 82^{\circ} 47.25^{\prime} \mathrm{E}$, in $2253 \mathrm{~m}$ water depth; Site 744 at $61^{\circ} 34.66^{\prime} \mathrm{S}, 80^{\circ} 35.46^{\prime} \mathrm{E}$, in $2307 \mathrm{~m}$ water depth (Fig. 1). The Kerguelen Plateau is about $2500 \mathrm{~km}$ long and $500 \mathrm{~km}$ wide, and is the world's largest submarine plateau. It stretches northwest-southeast from about $45^{\circ} \mathrm{S}$ to $65^{\circ} \mathrm{S}$ and rises 2-4 km above the adjacent Australian-Antarctic Basin to the east, the Crozet Basin to the north, and the African-Australian Basin to the west. The sites are situated about $1500 \mathrm{~km}$ south of the Antarctic Convergence, or Polar Front. This seasonally fluctuating water mass boundary separates the cold Antarctic Surface Water in the south from the warmer Subantarctic Surface Water to the north. Another important hydrographic feature, the Antarctic Divergence, is situated south of 


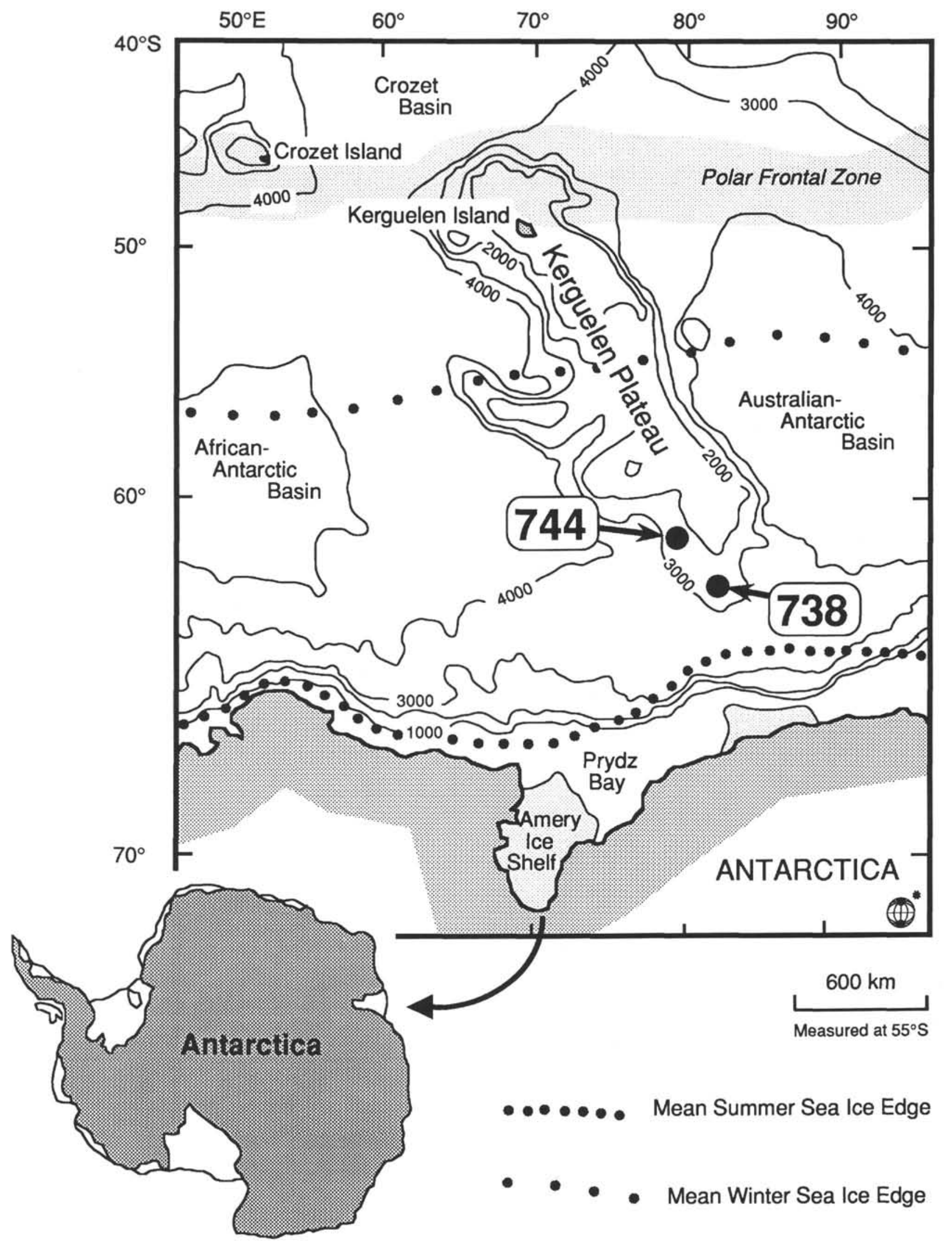

Figure 1. Location map of Leg 119 Sites 738 and 744. Bathymetry (in meters) is from GEBCO (Hayes and Vogel, 1981; Fisher et al., 1982). The position of the Polar Frontal Zone is according to Whitworth (1988), the mean sea ice coverage in summer and winter time according to Dietrich and Ulrich (1968). 
the two sites, at about $65^{\circ} \mathrm{S}$. The Antarctic Divergence separates the eastward-flowing Antarctic Circumpolar Current (Whitworth, 1988) to the north from the westward-flowing Antarctic Coastal Current to the south.

Site 738 yielded a 486-m-thick lower Turonian to Quaternary pelagic sequence that overlies volcaniclastic rocks and altered basalts (Barron, Larsen, et al., 1989). Biogenic calcareous sediments dominate the Cretaceous and Paleogene section. They gradually pass upward from limestone into calcareous chalk and nannofossil ooze. The limestone and chalk of Turonian to middle Eocene age contain varying amounts of chert nodules. The thin Neogene section is separated from the Paleogene section by a hiatus spanning early Oligocene to late Miocene time. The upper Miocene to Holocene sediments are characterized by diatom ooze with minor concentrations of foraminifers, calcareous nannofossils, and radiolarians. The recovery was almost $100 \%$ in the upper $130 \mathrm{~m}$ of Hole 738B (Fig. 2) and decreased abruptly to an average of about $45 \%$ with the occurrence of chert and the change to rotary drilling in Hole $738 \mathrm{C}$ (Barron, Larsen, et al., 1989).

Because the Neogene section at Site 738 was abnormally thin compared with its seismically estimated thickness in nearby areas, Site 744 was drilled in order to recover a thicker and more complete Neogene section. The drilling was successful and gained a 176-m-thick upper Eocene to Quaternary sedimentary succession (Fig. 3). Recovery was about $82 \%$ in Hole $744 \mathrm{~A}$ and $100 \%$ in Holes 744B and 744C. The latter two holes were drilled to enhance the recovery from Hole 744A and to provide more material for special scientific studies (Barron, Larsen, et al., 1989). The sediments recovered at Site 744 are highly pelagic and have a biogenic content of more than $90 \%$. The upper Eocene to upper Miocene sediments are characterized by nannofossil ooze, and the uppermost Miocene to Holocene sediments by soft diatom ooze.

\section{METHODS}

Bulk-sediment samples for this study were collected aboard JOIDES Resolution during Leg 119 and later at the ODP Repository at Lamont-Doherty Geological Observatory. Samples were taken, where possible, at 1.5-3-m intervals from Holes 738B, 738C, and 744A. The uppermost $15 \mathrm{~m}$ from Site 738 was not sampled and analyzed because of a condensed and interrupted stratigraphic record and because this stratigraphic interval could be studied in more detail at Site 744. Sample size was $10-20 \mathrm{~cm}^{3}$. Due to pressure release during the retrieval of sediment cores from the great water depth, recovery sometimes exceeded $100 \%$. Depth information in this paper is corrected for core recoveries $>100 \%$.

\section{Carbonate and Organic Carbon}

Total carbon content and inorganic carbon were determined on freeze-dried and ground bulk subsamples using a Coulomat 702 (Ströhlein Instruments). Gravel components and chert fragments were removed prior to grinding. Total carbon was set free by heating the sample to $1100^{\circ} \mathrm{C}$. Inorganic carbon was released by treatment with $14 \%$ phosphoric acid. Organic carbon and carbonate $\left(\mathrm{CaCO}_{3}\right)$ contents were calculated as weight percent. Available shipboard data (Barron, Larsen, et al., 1989) were incorporated into the author's data set.

\section{Grain Size and Biogenic Opal}

Bulk samples were disaggregated by freeze-drying and subsequent treatment with $10 \% \mathrm{H}_{2} \mathrm{O}_{2}$. Carbonate was removed with $10 \%$ acetic acid. The residue was washed through 2-mm and 63$\mu \mathrm{m}$ sieves to separate the gravel and sand fractions. The clay fraction $(<2 \mu \mathrm{m})$ was separated from the $<63-\mu \mathrm{m}$ fraction by decantation (settling time based on Stokes' law). In order to quantify the opal content and to remove the biogenic opaline components from the terrigenous sedimentary particles, such as quartz, feldspar, and rock fragments, a density separation was performed on the sand and silt fractions. A sodium-polytungstate solution was used as a heavy liquid, with its density adjusted to $2.3 \mathrm{~g} / \mathrm{cm}^{3}$. The separation was carried out in a centrifuge. Amorphous silica (mainly diatom debris) was removed from the $<2-\mu \mathrm{m}$ fraction quantitatively by a $3-\mathrm{min}$ treatment with a boiling 2 molar $\mathrm{Na}_{2} \mathrm{CO}_{3}$ leach.

\section{Clay Mineralogy}

The clay mineral composition was analyzed by X-ray diffraction (XRD) of the carbonate-free and opal-free $<2-\mu \mathrm{m}$ fraction. All samples were washed free of salt. The samples were fixed as texturally oriented aggregates on aluminium sample holders and solvated with ethylene-glycol vapor at $60^{\circ} \mathrm{C}$ for about $18 \mathrm{hr}$ immediately before the analyses. The measurements were conducted on an automated powder diffractometer system PW 1700 (Philips) with CoK $\alpha$ radiation ( $40 \mathrm{kV}, 40 \mathrm{~mA}$ ), graphite monochromator, automatic divergence slit, and an automatic sample changer. The samples were X-rayed from $2^{\circ}$ to $40^{\circ}$ $2 \theta$ with a speed of $0.02^{\circ} 2 \theta / \mathrm{s}$. The individual clay minerals were identified by their basal reflections at $15-18 \AA$ (smectite), $10 \AA$ (illite), 7 and $3.57 \AA$ (kaolinite), and 14.2, 7, 4.72, and $3.54 \AA$ (chlorite). Using empirically estimated weighting factors on integrated peak areas of the individual clay mineral reflections from the glycolated samples, semiquantitative evaluations of the clay mineral assemblage were made (Biscaye, 1964, 1965; Lange, 1982). Because the weighting factors were calculated for a fixed slit, using an automatic slit resulted in a slight shift of the actual concentrations. However, because only relative changes in the concentration patterns of the individual clay minerals are considered in this paper, this inaccuracy seems acceptable.

\section{Age Estimates}

All age estimates given in this paper are based on the shipboard stratigraphy (Barron, Larsen, et al., 1989), diatom stratigraphy (Baldauf and Barron, this volume), the biostratigraphio synthesis including the magnetostratigraphy of Site 744 (Barron et al., this volume), and the time scales by Berggren et al. (1985) and Aubry et al. (1988).

\section{RESULTS}

\section{Bulk-Sediment Composition}

\section{Carbonate}

\section{Site 738}

The carbonate concentration at Site 738 is generally very high and over long core intervals shows only minor fluctuations (Fig. 2 and Appendix Tables 1 and 2). In the lower part of the site, the lower Maestrichtian and deeper sediments, the carbonate concentrations are $80 \%-90 \%$. In the upper Maestrichtian to lower Oligocene sediments they are even higher and range from $90 \%$ to $98 \%$. An abrupt decrease in carbonate content occurs in the upper Miocene sediments overlying the lower Oligocene/upper Miocene hiatus at $18 \mathrm{~m}$ below seafloor (mbsf). Concentrations are almost zero in the lower part of the Pliocene section, increase to $60 \%-80 \%$ in the upper Pliocene and lower Quaternary section, and then again show a decreasing trend in the most recent sediments (Fig. 2).

\section{Site 744}

In the upper Eocene to lowermost Oligocene sediments of Site 744 , the carbonate content is nearly constant and exceeds $90 \%$ of the bulk sediment (Fig. 3), revealing the same trend as 


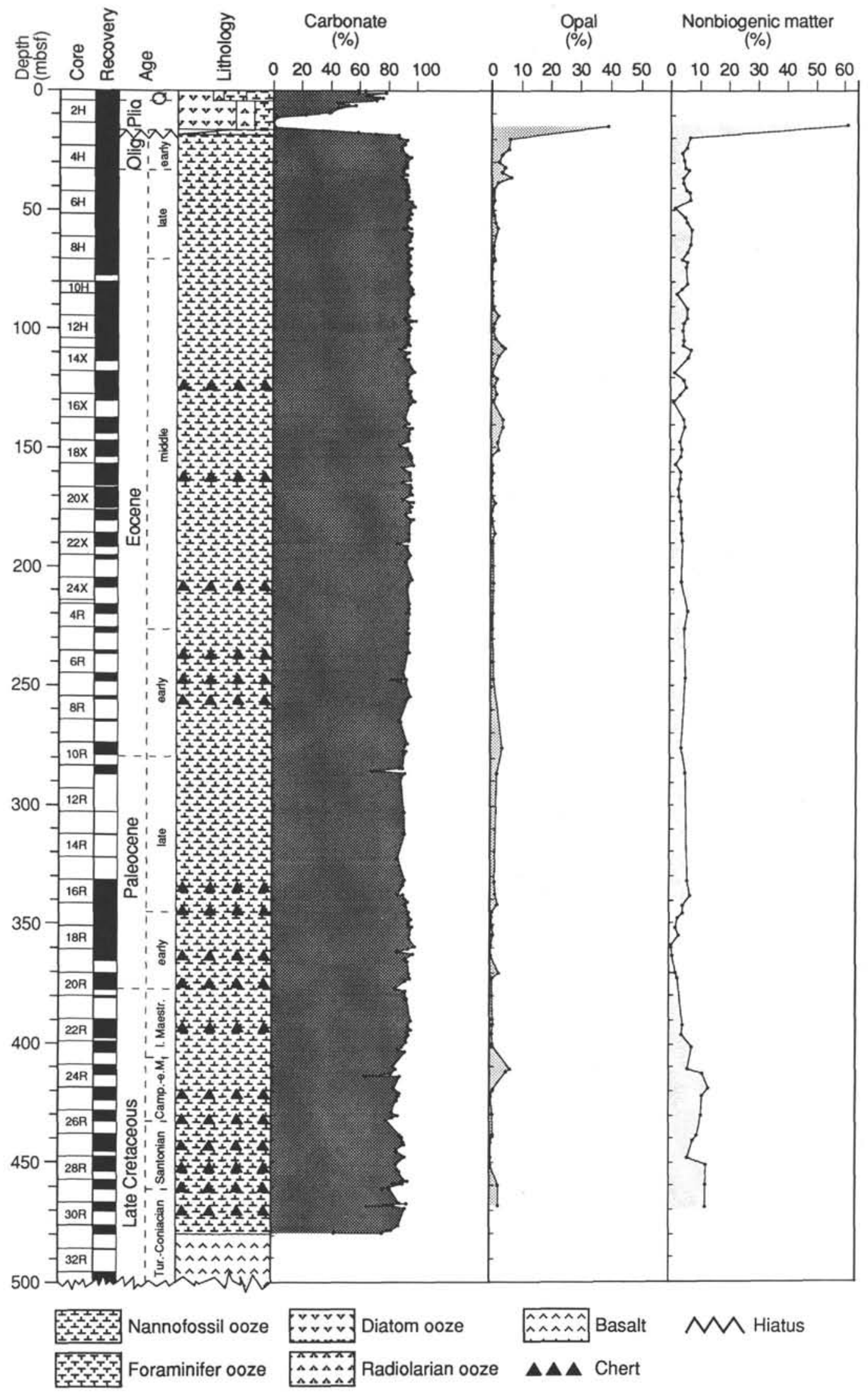

Figure 2. Sediment composition at Holes $738 \mathrm{~B}$ (Cores $1 \mathrm{H}$ through $24 \mathrm{X}$ ) and $738 \mathrm{C}^{\prime}$ (Cores $4 \mathrm{R}$ through $33 \mathrm{R}$ ). Carbonate concentration is based on the author's and shipboard data (Barron, Larsen, et al., 1989). 

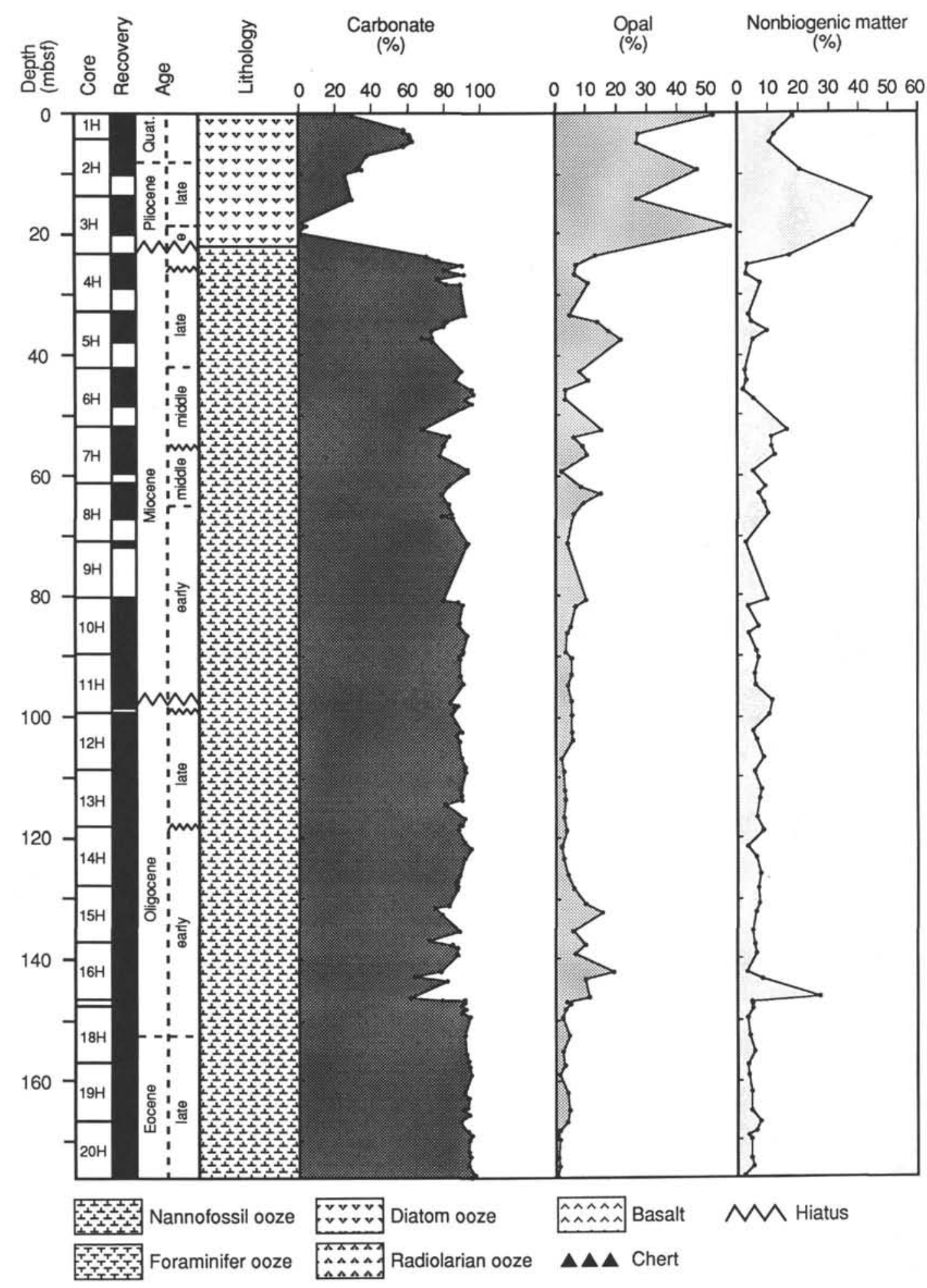

Figure 3. Sediment composition at Hole 744A. Carbonate concentration is based on the author's and shipboard data (Barron, Larsen, et al., 1989).

the corresponding sediments at Site 738 (Fig. 2). The carbonate concentration abruptly decreases to $60 \%$ at 146 mbsf (Fig. 3). This event has an age of $36.0 \mathrm{Ma}$, based on the shipboard stratigraphy (Barron, Larsen, et al., 1989) and on the studies of Baldauf and Barron (this volume) and Barron et al. (this volume).
Younger sediments were either not recovered at Site 738 or were condensed. At Site 744, however, a detailed picture of the development of carbonate concentrations through Oligocene and Neogene time can be drawn. After the event at 36.0 Ma the carbonate concentrations slowly rise again and reach a constant level of $90 \%$ in the upper part of the lower Oligocene sediments. 
This level is maintained through the upper Oligocene and lower Miocene sediments. Two further weak minima in carbonate content occur in the Miocene. The first one comprises the lower middle Miocene; the second one the lower part of the upper Miocene. In both cases concentrations fall to $70 \%-80 \%$.

A distinct fall of carbonate concentrations was initiated in latest Miocene time and was completed in the lower Pliocene interval, where sediments are almost devoid of carbonate (Fig. 3). Subsequently, concentrations rise to $20 \%-40 \%$ in the upper Pliocene and to $60 \%$ in the middle part of the Quaternary, before they decrease again in the youngest sediments. This Pliocene to Quaternary trend can also be seen in a condensed form at Site 738 (Fig. 2).

\section{Organic Carbon}

The organic carbon content was determined on a few samples from Site 744 only (Appendix Table 1) and is not presented graphically. These results and those of the shipboard analyses (Barron, Larsen, et al., 1989) show that the concentration of organic carbon is generally $<0.1 \%$ in sediments from both Sites 738 and 744.

\section{Opal}

\section{Site 738}

The opaline components at Site 738 consist exclusively of radiolarians in the pre-Oligocene lower part of the site and of mixed diatoms and radiolarians in the upper part. Silicoflagellates and sponge spicules also occur, but are quantitatively unimportant in the upper part. Several small and isolated maxima in the opal concentrations of the bulk sediment are present in the Cretaceous and Paleogene sediments of Site 738 (Fig. 2 and Appendix Table 1). The concentrations, however, do not exceed $7 \%$ of the bulk sediment. Most of the maxima correlate with reported occurrences of radiolarians (Barron, Larsen, et al., 1989). The most prominent maxima occur in the upper Campanian to lower Maestrichtian and in the middle part of the middle Eocene.

Some opaline material is also present in the upper Eocene sediments, and a slight increase in concentrations to $5 \%$ occurs just below the Eocene/Oligocene boundary. The latter cannot be ascribed to radiolarians alone, but also to the small number of poorly preserved diatoms reported in this interval (Barron, Larsen, et al., 1989). A pronounced increase in opal content, mainly from diatoms, is documented in the upper part of Core 119-738B-3H (Fig. 2). It is difficult to date precisely the onset of diatom ooze sedimentation, because it occurs within a $2-\mathrm{m}$ thick core interval containing three hiatuses and probably a condensed section between the hiatuses (Barron, Larsen, et al., 1989 , p. 246). Pure nannofossil ooze accumulation ceased at a hiatus spanning approximately 35-10 Ma. A transition to more diatom-rich sediments occurred between 10 and $8.4 \mathrm{Ma}$, when another hiatus interrupted the sedimentary record. Above this hiatus, at $6.1 \mathrm{Ma}$, diatom ooze accumulation with opal concentrations of up to $90 \%$ had started, but was interrupted by a further hiatus spanning $>5.8-<4.8 \mathrm{Ma}$ (Barron, Larsen, et al., 1989).

\section{Site 744}

The opaline material of sediments from Site 744 is composed mainly of diatoms and, to a minor degree, radiolarians. Silicoflagellates and sponge spicules occur in small quantities. Opal at Site 744 first appears in detectable amounts of about $4 \%$ at 167 mbsf. The onset of accumulation of biosiliceous components, even if in small amounts, therefore has a late Eocene age of $38.4 \mathrm{Ma}$. Shipboard paleontologists found the oldest diatoms and radiolarians, which were few in number and poorly pre- served, in the lower Oligocene at 158 mbsf (Barron, Larsen, et al., 1989). Both groups of siliceous microfossils are then consistently present and moderately to well preserved throughout the Oligocene to Quaternary sediments (Fig. 3 and Appendix Table 1).

The first maximum with $5 \%-20 \%$ opaline matter at Site 744 occurs in the lower Oligocene $(36.0 \mathrm{Ma})$ and correlates with a diminished carbonate concentration (Fig. 3). In the upper part of the lower Oligocene and lower Miocene, opal concentrations are low again, at about $5 \%$ of the bulk sediment consisting of diatoms and radiolarians. In the middle and upper Miocene section the opal content is similar to that in the lower Oligocene, but fluctuates widely between $5 \%$ and $20 \%$. Greatly increased opal contents occur at Hole $744 \mathrm{~A}$ above the upper Miocene/Pliocene hiatus between Cores 119-744A-4H and 119-744A-3H. Relatively poor recovery rates in this part of Hole 744A hamper an exact dating. In Hole $744 \mathrm{~B}$, which had a $100 \%$ recovery, the transition from nannofossil ooze to diatom ooze occurs above a hiatus dated 9.0-6.0 Ma and just below another hiatus dated 5.5-4.0 Ma. In Hole 744C the transition occurs approximately 1 $\mathrm{m}$ below the Miocene/Pliocene boundary, but cannot be dated more accurately because of the lack of detailed biostratigraphic studies. The onset of diatom ooze accumulation at Site 744 thus started in latest Miocene time, at 5.8-5.6 Ma.

The Pliocene to Holocene sediments are characterized by opal concentrations between $25 \%$ and $60 \%$. Estimates based on smear slide analyses indicate even higher values of up to $80 \%$ (Barron, Larsen, et al., 1989).

\section{Nonbiogenic Matter}

\section{Site 738}

Sediments recovered at Site 738 contain approximately $5 \%$ nonbiogenic matter (Fig. 2 and Appendix Table 1). Only two intervals are characterized by higher values. Concentrations of up to $13 \%$ are recorded in the Turonian to lower Maestrichtian sediments, and the nonbiogenic matter consists mainly of clay minerals (Fig. 6). Concentrations of up to at least $50 \%$ characterize the upper Miocene to Quaternary interval.

\section{Site 744}

The standard level of $5 \%$ nonbiogenic matter at Site 738 is also found in the upper Eocene to lowermost Oligocene sediments of Site 744 (Fig. 3 and Appendix Table 1). A sharp peak $(27 \%)$ in the concentration of nonbiogenic matter obviously matches the drop in carbonate concentration and the increase in opal content in the lower Oligocene at $36.0 \mathrm{Ma}$. Concentrations tend to be about $8 \%$ in the remaining Oligocene section and in the lower Miocene sediments, about $10 \%-15 \%$ in the middle Miocene, and about $5 \%$ in the upper Miocene. The increase in the uppermost Miocene and Pliocene to $40 \%$ of the bulk sediment correlates with changes in concentration of carbonate and opal. A clear maximum occurs in the upper lower to lower upper Pliocene interval.

\section{Grain-Size Distribution of Nonbiogenic Matter}

\section{Results from Core Descriptions}

\section{Site 738}

The lowermost coarse terrigenous material detected at Site 738 during core description is an angular granite clast in Section 119-738B-8H-1. This gravel occurs in sediment that is about $40.5 \mathrm{Ma}$ old, but it probably can be ascribed to contamination due to hole cave-in (Barron, Larsen, et al., 1989). The same is true for gravel found along the core liner of Section 119-738B7H-1 (Fig. 4). 
From Section 119-738B-3H-5, $35 \mathrm{~cm}$, to the top of Hole $738 \mathrm{~B}$, coarse terrigenous particles are scattered throughout the sediments. The oldest ice-rafted debris belongs to the early Oligocene foraminifer Zones P18-20 and diatom Zones CP15b-16 (Barron, Larsen, et al., 1989). Thus, the inferred maximum age is about $36 \mathrm{Ma}$. The Neogene ice-rafted debris is composed of granitic and gneissic clasts several centimeters in diameter, as well as of pebble-, granule-, and sand-sized grains consisting mainly of quartz. Most grains are coated with manganese oxide and are angular to subangular (Barron, Larsen, et al., 1989).

\section{Site 744}

The lowermost gravel and coarse sand grains visible in a cut core surface from Site 744 were found scattered through the interval from Sections 119-744A-20H-1, $0 \mathrm{~cm}$, to 119-744A-20H2, $57 \mathrm{~cm}$ (Fig. 5). Biostratigraphic data indicate a late Eocene age of about $38.5 \mathrm{Ma}$ (Barron et al., this volume). This interval of the core, however, is very disturbed by drilling, and the recovered nannofossil ooze has a soupy character. The grains float in the host sediment mass. The lowermost granule was found in the transition zone from soupy to firm sediment. The firmer part of Section 119-744A-20H-2 was X-rayed aboard ship, but no coarse sediment grains could be detected. All coarse material in this interval is therefore thought to be due to downhole contamination.

The next appearance of coarse grains is in Core 119-744A$17 \mathrm{H}$ (Fig. 5), which has a core length of only $0.90 \mathrm{~m}$ and a recovery of $0.83 \mathrm{~m}$. The alignment of most of the granules along the core liner suggests an origin by downhole contamination. Some other grains, however, occur within a firm host sediment and are in situ (Barron, Larsen, et al., 1989). One of the icerafted grains is $2 \mathrm{~cm}$ in diameter and consists of a manganese oxide-coated gneiss. The other grains comprise numerous disseminated quartz granules of 1-4 mm diameter and some small manganese oxide-coated pebbles. According to the magnetostratigraphic interpretation (Barron et al., this volume), Core $119-744 \mathrm{~A}-17 \mathrm{H}$ is situated just beneath magnetic anomaly 13 (35.9-35.3 Ma; Berggren et al., 1985; Aubry et al., 1988). This implies an age of about 36.2-35.9 Ma for the core.

Also found in the lower Oligocene interval from Sections $119-744 \mathrm{~A}-16 \mathrm{H}-7$ to $119-744 \mathrm{~A}-16 \mathrm{H}-\mathrm{CC}$ was a large quantity of unequivocally ice-rafted granules. The grains are angular and are mainly $1-4 \mathrm{~mm}$ in diameter. This occurrence is at the base of magnetic anomaly 13 , and therefore is $35.9 \mathrm{Ma}$ old. The pulse of early Oligocene ice rafting is assumed to be contemporaneous with that at Site 738. An exact correlation, however, is not possible because of the lack of paleomagnetic data from Site 738.

In the middle part of the core recovery from Site 744 no icerafted pebbles and granules were detected in the cores. The next ones occur in the upper Miocene to Quaternary sediments of Core 119-744A-1H to Section 119-744A-4H-3, $100 \mathrm{~cm}(27.2$ mbsf; late Miocene, $9 \mathrm{Ma}$ ). The granules are mostly subangular, and some of the larger pebbles (up to $5 \mathrm{~cm}$ in diameter) are subrounded. Most of the clasts, which include quartz, granite, gneiss, and amphibolite, are coated by manganese oxide.

\section{Results from Grain-Size Analyses}

\section{Site 738}

The deepest occurrence of gravel-sized components in samples from Site 738 was in the lower Paleocene at 352 mbsf (Fig. 4 and Appendix Table 3). The gravel consists of chert fragments probably created during rotary drilling and transferred downcore. Two samples from 104 and 85 mbsf contained one subangular gneissic or granitic rock fragment each. Both samples are from core sections that did not show any indications for con- tamination. Stratigraphically they belong to the middle Eocene (Barron et al., this volume); their absolute age is $43.5-42.3 \mathrm{Ma}$. The next and youngest gravel occurs in the uppermost sample investigated, in Section 119-738B-3H-1, and has an early Pliocene age.

The sand-sized nonbiogenic material has a concentration pattern characterized by numerous, but mainly isolated, peaks (Fig. 4 and Appendix Table 3). Most of the samples, however, did not contain measurable amounts of nonbiogenic sand. The enhanced sand occurrence in the Paleocene cores is caused by chert fragments generated during rotary drilling and probably smeared along the liner during coring and along the cut surface during splitting of the cores. The small maxima in Cores 119738C-7R and 119-738B-16X are due to authigenic minerals. The lowermost detrital sand grains are found at a depth of $131 \mathrm{mbsf}$, i.e., deeper than the first terrigenous gravel component. They consist mainly of angular to subangular quartz grains and some feldspar. According to the biostratigraphy and the derived sedimentation rates (Barron et al., this volume), the core interval has a middle Eocene age of about $45.0 \mathrm{Ma}$. The next terrigenous sand grains occur at 109 and 104 mbsf. These grains comprise subangular igneous rock fragments and a subrounded reddish sandstone fragment and have a middle Eocene age of about 44-43.5 Ma. In the lower Oligocene, at $20 \mathrm{mbsf}$, subangular quartz grains are the dominant constituent of the nonbiogenic sand fraction. The highest concentration of the sand-sized fraction of the nonbiogenic components of Site 738 was found in the sample from lower Pliocene Section 119-738B-3H-1.

The silt grain sizes of the nonbiogenic matter (Fig. 4 and Appendix Table 3) in the lower part of Site 738 are controlled by drilling breccias of chert nodules. In the upper part of the site three maxima can be identified, with the first one in the middle part of the middle Eocene, between 180 and 140 mbsf. The second maximum comprises the youngest interval of the middle Eocene at 90-70 mbsf, and the third one characterizes the top of the site and starts in the lower Oligocene sediments.

The clay fraction at Site 738 is the dominant grain-size fraction of the nonbiogenic material. Its concentration pattern is opposite that of nonbiogenic sand and silt (Fig. 4 and Appendix Table 3).

\section{Site 744}

The deepest occurrence of gravel in samples from Hole 744A is in Core 119-744A-20H (Fig. 5 and Appendix Table 3). According to the preceding discussion, this is due to contamination. The next gravel was found in Samples 119-744A-17H-CC, $12-14 \mathrm{~cm}$, and $119-744 \mathrm{~A}-16 \mathrm{H}-7,47-49 \mathrm{~cm}$, which have an early Oligocene age of about $36 \mathrm{Ma}$. Higher in the core, only Sample 119-744A-3H-1, 49-51 cm, which has a Pliocene age, contained gravel.

The sand-sized nonbiogenic material (Fig. 5 and Appendix Table 3) in the Eocene and early Oligocene age sediments shows the same concentration pattern as the gravel component. At the early Oligocene peak occurrence, up to $38 \%$ of the nonbiogenic material is sand sized. The remainder of the Oligocene and the Miocene part of the sequence recovered at Hole 744A are characterized by very low terrigenous sand concentrations. A slight increase is documented at $26 \mathrm{mbsf}(9.0 \mathrm{Ma})$, but cannot be followed into younger sediments because of a hiatus. A dramatic increase in sand-grain size was found in Section 119-744A-4H-1 (24 mbsf), which represents the uppermost Miocene, and has an age range of about 5.7-5.8 Ma. From the uppermost Miocene to Holocene, $10 \%$ to $30 \%$ of the nonbiogenic sediment components occurs in the sand fraction.

The nonbiogenic material does not reveal very distinct maxima and minima in its silt concentration pattern (Fig. 5 and Appendix Table 3). However, after very low values in the Eocene in- 


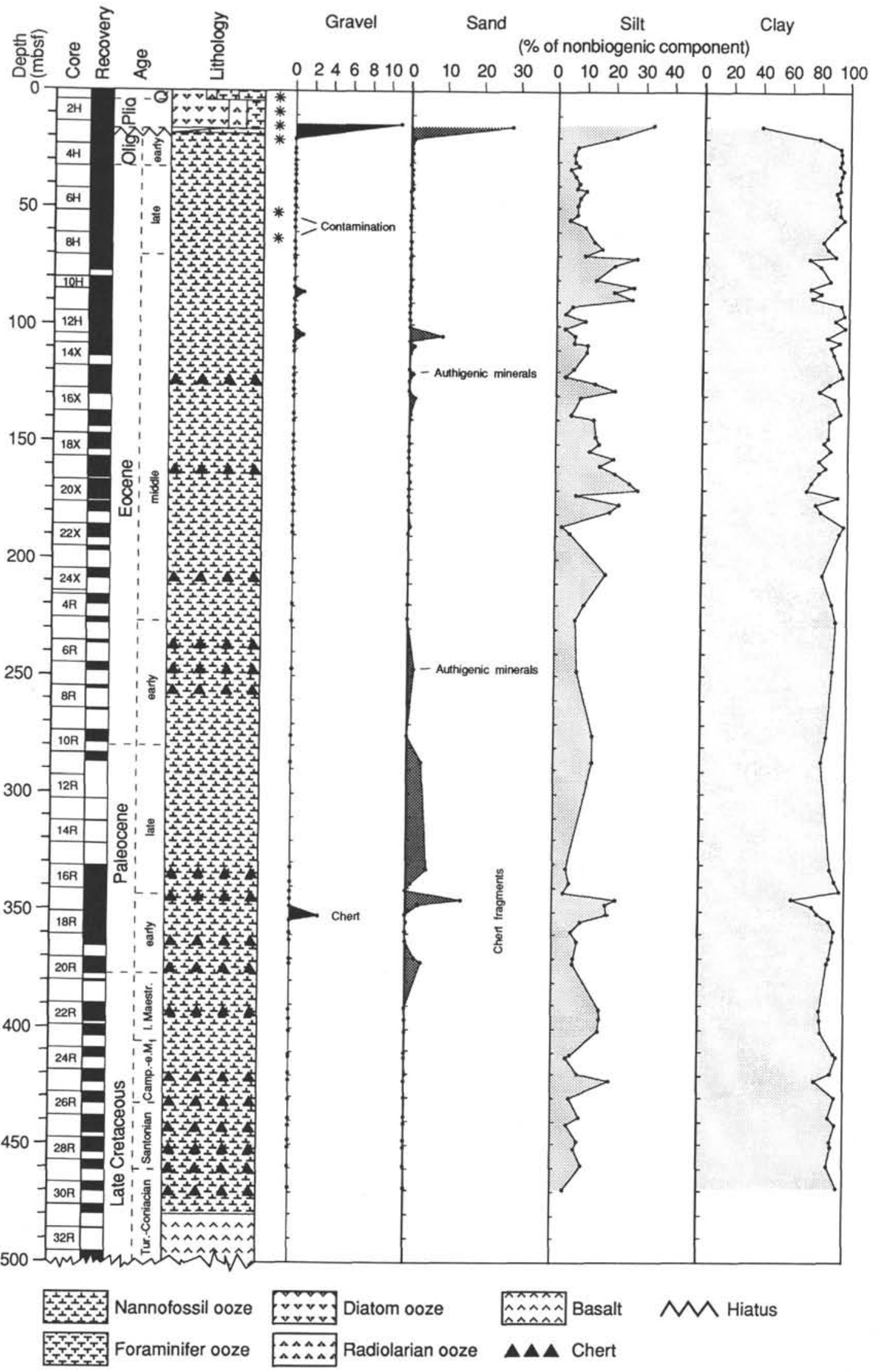

Figure 4. Gravel content and grain-size distribution of the nonbiogenic sediment components at Holes 738B (Cores $1 \mathrm{H}$ through $24 \mathrm{X}$ ) and $738 \mathrm{C}$ (Cores $4 \mathrm{R}$ through 33R). Asterisks indicate occurrences of gravel according to visual core description (Barron, Larsen, et al., 1989). Gravel concentration is the number of pebbles and granules in the investigated samples. 

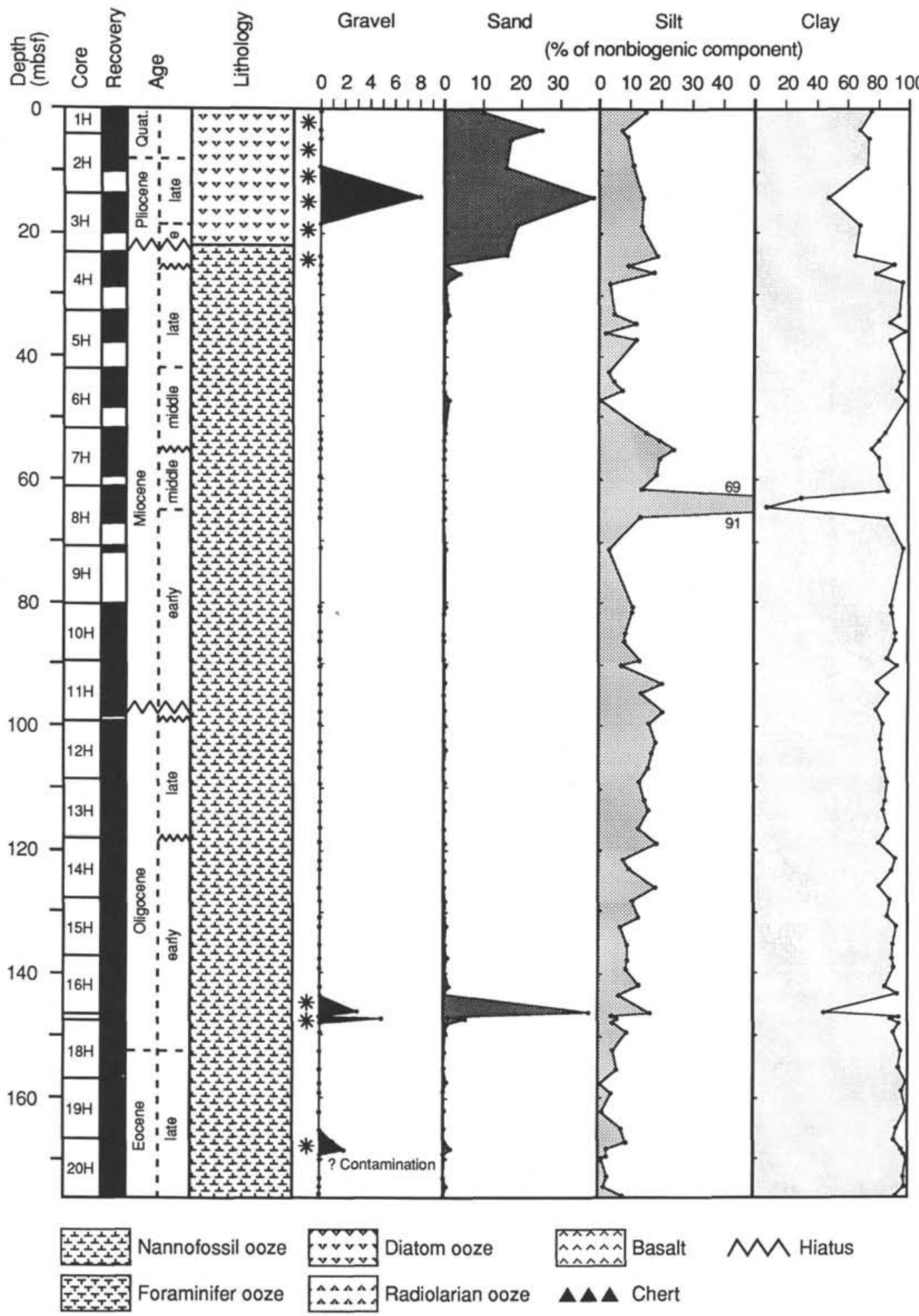

Figure 5. Gravel content and grain-size distribution of the nonbiogenic sediment components at Hole 744A. Asterisks indicate occurrences of gravel according to visual core description (Barron, Larsen, et al., 1989). Gravel concentration is the number of pebbles and granules in the investigated samples.

terval, there is a slightly increasing trend from the lowermost Oligocene to the lowermost Miocene (155-93 mbsf). The concentrations rise upcore from about $5 \%$ to $20 \%$. They then decrease to the base of Core 119-744A-8H. The next maximum in nonbiogenic silt-sized material occurs in the lower part of the middle Miocene interval. In younger sediments the concentra- tions are lower, with minimum values in the upper middle and lower upper Miocene.

The clay fraction is the dominant grain-size fraction of the nonbiogenic material at Hole 744A. Its concentration pattern is opposite that of the nonbiogenic sand and silt (Fig. 5 and Appendix Table 3). 


\section{Clay Minerals}

\section{Site 738}

At Site 738 most of the nonbiogenic sediment is in the $<2$ $\mu \mathrm{m}$ fraction. Therefore, there is a strong correlation between the concentration patterns of nonbiogenic matter and clay in the bulk sediment (Figs. 2 and 6).

The clay fractions of the Cretaceous, Paleocene, and Eocene sediments (470-40 mbsf) are dominated by smectites (Fig. 6 and Appendix Table 4). In addition, between about 130 and 470 mbsf some randomly interstratified mixed-layer illite-smectites occur. The smectite share (including the mixed layers) of the clay mineral assemblage in this lower part at Site 738 is generally $>90 \%$. Only at $470-455$ and $410-380$ mbsf do concentrations drop to $70 \%-85 \%$. A distinct fall in smectite concentration starts in the upper Eocene interval at $\mathbf{4 2}$ mbsf and reaches a first minimum of $59 \%$ at $36 \mathrm{mbsf}$ in the uppermost Eocene ( $38 \mathrm{Ma}$ ). Only $4 \mathrm{~m}$ higher in the core, the next maximum with $97 \% \mathrm{smec}$ tite is reached in the lowermost Oligocene sample, followed by decreasing values.

Illite concentrations show a strong negative correlation with the smectite abundance. Chlorites occur at Site 738 in the preOligocene sediments below $40 \mathrm{mbsf}$, but only in traces. An exception is the interval from 150 to $130 \mathrm{mbsf}$, which has chlorite concentrations of $5 \%-10 \%$. In the upper part of the upper Eocene interval, at $40 \mathrm{mbsf}$, chlorite rises to $15 \%$. After a minimum at 32 mbsf the values are $>10 \%$ (Fig. 6). The kaolinite content shows a pattern similar to that of chlorite, with trace amounts in the deeper part of the site, a small maximum of $5 \%-7 \%$ at $150-130 \mathrm{mbsf}$, and a clear increase to values of about $6 \%-10 \%$ at 40 mbsf.

\section{Site 744}

The percentage of clay minerals in the bulk sediment of Hole $744 \mathrm{~A}$ is relatively low and reflects the highly pelagic character of the depositional environment on southern Kerguelen Plateau (Fig. 7 and Appendix Table 4). From the bottom of the hole at 176 mbsf to about 24 mbsf the clay concentrations generally range from $3 \%$ to $10 \%$. Fluctuations are only minor, but slight maxima occur at $146 \mathrm{mbsf}$ (early Oligocene, $36 \mathrm{Ma}$ ) and at 5257 mbsf within the middle Miocene. A distinct increase in clay content can be observed in the uppermost upper Miocene inter$\mathrm{val}$ at 24 mbsf. A maximum of $26 \%$ is reached at the boundary between the lower and upper Pliocene at 19 mbsf. Generally decreasing values characterize the overlying sedimentary sequence.

The smectite concentrations in the lower part of Hole 744A are relatively high (Fig. 7 and Appendix Table 4). Between the bottom of the hole and $150 \mathrm{mbsf}$, in the upper Eocene and lowermost Oligocene sediments, they follow a slightly decreasing trend from about $90 \%$ to $70 \%$. A short-lived minimum indicated by one sample from Section 119-744A-19H-1 (late Eocene, $37.5 \mathrm{Ma}$ ) possibly correlates with a short minimum at Site $738(38.0 \mathrm{Ma})$. A sharp and almost continuous drop to a minimum value of $16 \%$ occurs in lower Oligocene sediments between 150 and $142 \mathrm{mbsf}$ (36.5-35.5 Ma), and also correlates with Site 738 . The interval $142-95$ mbsf is characterized by smectite concentrations fluctuating at about $40 \%$. A short maximum of about $50 \%-60 \%$ follows in the lower half of the lower Miocene interval. Values of about $40 \%$ occur again from 81 mbsf to the surface, with a slight and indistinct maximum in upper Miocene sediments between 37 and 18 mbsf.

Smectite, together with illite, accounts for $70 \%-90 \%$ of the clay minerals present in the Hole $744 \mathrm{~A}$ sediments. They show a strong negative correlation $(r=-0.93)$. Changes in the illite concentrations are therefore not discussed here. Chlorite contents are low $(<4 \%)$ in the deepest $10 \mathrm{~m}$ at Hole 744A. An increase to about $5 \%-10 \%$ occurs at 165 mbsf, and a maximum of $20 \%$ is reached between 147 and 142 mbsf. Further up in the core the chlorite concentrations fluctuate between $5 \%$ and $15 \%$ without any significant changes in the distribution pattern (Fig. 7). The kaolinite occurrence is restricted to trace amounts in the deepest part of Hole 744A. The first significant concentrations appear in the upper Eocene at 165 mbsf. A maximum concentration of $26 \%$ is found in the lower Oligocene at $146 \mathrm{mbsf}$. Upcore, the concentrations fluctuate between mainly $2 \%$ and $12 \%$ with no particularly obvious pattern.

\section{DISCUSSION}

\section{Environmental Implications of the Sediment Composition}

The latest Miocene to Quaternary sediments at the southern Kerguelen Plateau Sites 738 and 744 consist predominantly of diatom ooze with a variable carbonate content (Figs. 2 and 3 ). The older sediments are nannofossil ooze, chalk, and limestone with a minor biosiliceous and almost negligible nonbiogenic content. The opaline components essentially disappear below the Eocene/Oligocene boundary, but their former presence and their diagenetic alteration are documented by the occurrence of porcellanite and chert nodules in middle Eocene and older sediments.

The sediments of Site 738 roughly document the subsidence history of the southern Kerguelen Plateau (Barron, Larsen, et al., 1989). Algal calciclastic limestones were deposited in a shallow-water inner shelf setting during Turonian time. A slight deepening equivalent in depth to a shelf break setting by the end of the Cretaceous Period is indicated by the benthic shelly fauna, trace fossil assemblages, and omission surfaces associated with glauconite. Deepening continued, and deposition of pelagic oozes took place at or near the present-day water depth throughout most of the Cenozoic Era.

The presence of at least small amounts of carbonate at Sites 738 and 744 (Figs. 2 and 3 ) indicates that the two sites have remained above the carbonate compensation depth (CCD) since Late Cretaceous time. With the exception of a short interval in early Pliocene time, the sites also remained above the carbonate critical depth (CCrD, <10\% $\mathrm{CaCO}_{3}$; Kolla et al., 1976). The CCD in the present-day Indian Ocean is situated in about $5200 \mathrm{~m}$ water depth (Van Andel, 1975), and the CCrD at about $3900 \mathrm{~m}$ water depth (Kolla et al., 1976).

Although the carbonate percentages are very high (>90\%) and constant in the Eocene and older sediments, they fluctuate slightly from the lower Oligocene to the upper Miocene and strongly from the uppermost Miocene to the Holocene (Figs. 2 and 3 ). The transition from consistently high to slightly lower and fluctuating concentrations occurs abruptly at the base of Core $119-744 \mathrm{~A}-16 \mathrm{H}$, dated as early Oligocene at about $36 \mathrm{Ma}$. Compared with older and younger pure calcareous sediments, samples from Core 119-744A-16H are characterized by a much lower number of planktonic foraminifers and also by a benthic relict fauna (A. Mackensen, pers. comm., 1989). The reduced carbonate content is thought therefore to be caused, at least in part, by dissolution processes. The decrease in carbonate concentration at $36 \mathrm{Ma}$ correlates with a sharp peak in the concentrations of nonbiogenic matter of ice-rafted origin and with a first maximum in opal concentrations (Fig. 3).

Moderate to weak minima in the carbonate content occur at Site 744 in the lower Oligocene (146-130 mbsf; 36-34 Ma), at the transition between the lower and the middle Miocene (70-60 mbsf; 17.5-15.0 Ma), in the middle Miocene (57-48 mbsf; $14-$ $11 \mathrm{Ma}$ ), and in the lower upper Miocene (40-35 mbsf; $10.5-10.0$ $\mathrm{Ma}$ ). The minima coincide with times of major oxygen isotope increases signaling the cooling of Southern Ocean waters (Shackleton and Kennett, 1975). The cooling could have caused in- 
creased biosiliceous fertility (Barron, Larsen, et al., 1989), and thus a dilution of the calcareous sediment components, or increased aggressivity of the bottom water masses and resulting carbonate dissolution, as indicated for the lower Oligocene samples. At Leg 120 Site 751, approximately $400 \mathrm{~km}$ north of Site 744 , the minima in carbonate concentration are at least in part due to dissolution (A. Mackensen, pers. comm., 1989). A highresolution study of the Miocene to recent carbonate content, benthic foraminifer assemblages, and $\delta^{18} \mathrm{O}$ and $\delta^{13} \mathrm{C}$ isotopic data will be presented for that site (Mackensen et al., in press).

A transition from almost pure nannofossil ooze to predominantly diatom ooze sedimentation took place in latest Miocene time (Figs. 2 and 3). On the southernmost Kerguelen Plateau, at Site 738 , this transition is dated at $>6.1 \mathrm{Ma}$, and at Site 744 at $5.8 \mathrm{Ma}$. At Site 751 pure diatom ooze started to accumulate above a hiatus spanning the time interval 5.9-4.7 Ma (Mackensen et al., in press). It thus seems that the facies change gradually moved northward with time and possibly reflects the northward migration of the Polar Front. On the northern Kerguelen Plateau, at Site 737, diatom ooze sedimentation started earlier, at about $7 \mathrm{Ma}$. However, temperate low-latitude species make up an important part of the diatom assemblages there. A transition to assemblages dominated by Southern Ocean species occurred at 3.9 Ma at Site 737 (Barron, Larsen, et al., 1989). Replacement of a carbonate facies by an almost completely biosiliceous facies was also recorded in uppermost Miocene sediments recovered at $65^{\circ} \mathrm{S}$ on Maud Rise during ODP Leg 113 (Barker, Kennett, et al., 1988).

The decrease in carbonate concentrations in the lower Pliocene to values $<5 \%$ also can be explained by a drastic shoaling of the CCrD and the CCD. A cooling of the surface waters and the extension of ice shelves enhanced the production of cold bottom waters, which in turn caused an intensified bottom water circulation resulting in widespread hiatuses (Davies et al., 1975; Barron and Keller, 1982; Ciesielski et al., 1982). Shoaling of the lysocline and the CCD during the latest Miocene was reported for the South Atlantic (Hsü et al., 1984), but so far not for the southern Indian Ocean. The shallowest Cenozoic level of the lysocline and $\mathrm{CCD}$, however, was reported for the middle Miocene.

\section{Ice Rafting on Southern Kerguelen Plateau}

The temporal variation in concentration of ice-rafted debris is the most obvious indicator for strong climatic changes in and around Antarctica through time. In this paper, ice-rafted debris is used to date the onset of glaciation at sea level in East Antarctica and to reconstruct the Cenozoic glacial history.

Ice-rafted debris, such as that recovered on southern Kerguelen Plateau, is delivered to the distal marine environment mainly by icebergs calving from ice streams and outlet glaciers into the sea (Drewry, 1986). Coarse surface sediments can also be picked up on the continental shelf by drifting icebergs, which periodically become grounded and then transport the sediment into the adjacent seas (Kellogg and Kellogg, 1988).

In contrast, many icebergs calving from larger ice shelves consist of clean ice, because of melting at the base of the ice shelf. At the base of an ice shelf most of the terrigenous material melts out and settles on the shelf area soon after leaving the grounding line (Kellogg and Kellogg, 1988; Hambrey et al., this volume). Debris-laden icebergs calving from ice shelves can be observed when saline ice freezes onto the base of the ice shelf and thereby protects the debris from early release by melting processes, as is happening under the Amery Ice Shelf (Hambrey, this volume). The debris well inside the body of a calving iceberg may be released into the sea only when the berg disintegrates, a long way from the source. Another exception occurs when a grounded ice sheet, with sediment incorporated in its base, decouples from its bed, becomes unstable, and breaks into pieces, which then drift away.

Although ice-rafted sediment has all grain-size classes represented in roughly equal parts, most studies have used only the concentration of terrigenous sand or gravel as a measure of the ice-rafting intensity (e.g., Blank and Margolis, 1975; Bornhold, 1983; Grobe, 1986). The clay and silt fractions of sediments are not commonly used as an indicator of ice rafting, because this material could also originate from other sources, such as wind transport, turbidity currents, and bottom currents and because they are prone to postdepositional redistribution by current activity. However, in the highly pelagic setting of the southern Kerguelen Plateau, an origin for this material other than by ice rafting is not likely. Turbidites have not been observed in the sediments drilled at Sites 738 and 744 . They are not likely to occur in the morphologic setting presented by these sites, which are elevated more than $1000 \mathrm{~m}$ above the deep-water passage that separates Antarctica from the Kerguelen Plateau (Fig. 1). Wind transport was also probably much reduced when the Antarctic continent was glacierized. Transport by bottom currents is thought to have played only a minor role at the two sites, because through all the time represented by sediments, fine-grained sediment particles continuously accumulated in large amounts. A few hiatuses, however, mark erosive phases.

\section{Origin of the Ice-Rafted Debris}

Almost all of the gravel- and sand-sized rock fragments recovered from sediments at Sites 738 and 744 are of gneissic and, to a minor degree, granitic character. Even the terrigenous sand and silt, which mainly consist of quartz and feldspar, do not indicate a different source. The only major exception is a large grain of reddish sandstone, which was recovered from Section 119-738B-13H-1. The ice-rafted debris resembles the material found in Prydz Bay (Hambrey et al., this volume) and that found just east of the Kerguelen Plateau at Sites 745 and 746, which are situated in about $4000 \mathrm{~m}$ water depth in the Australian-Antarctic Basin (Ehrmann and Grobe, this volume; Ehrmann et al., this volume).

The clast composition is similar to that expected from a source area situated in East Antarctica. The geology of this part of the continent is characterized by widespread occurrences of Precambrian gneisses and migmatites, as well as some charnockites and schists (e.g., Craddock, 1982; Ravich and Fedorov, 1982; Trail and McLeod, 1969). The hard sandstone clast may be derived from an equivalent of Beacon Supergroup strata, which are widespread in various parts of Antarctica. The small amount of sedimentary rock fragments recovered may mirror the areal distribution of sedimentary as opposed to igneous and metamorphic source rocks in East Antarctica. It may also demonstrate that the sedimentary rocks were not sufficiently lithified to survive glacial transport, but were disaggregated into their individual mineral components.

The Kerguelen Plateau, with its widespread volcanism and islands, is not a likely source for the sediment particles deposited at Sites 744 and 738 , which lie on the southern tip of the plateau. Sedimentary calcareous clasts and basaltic components, which could be derived from the plateau, are totally missing.

\section{Ice Rafting Through Time}

The amount of ice-rafted debris at the sites is controlled by the source area of the icebergs, the iceberg frequency, and by the calving processes. These, in turn, are controlled by sea-level changes and the mass budget of the Antarctic ice sheet in response to climatic changes. Furthermore, the oceanography of the Southern Ocean plays an important role in the distribution of icebergs and is a crucial limiting factor in reconstructing the glacial history and the paleoclimate based on the record of ice- 


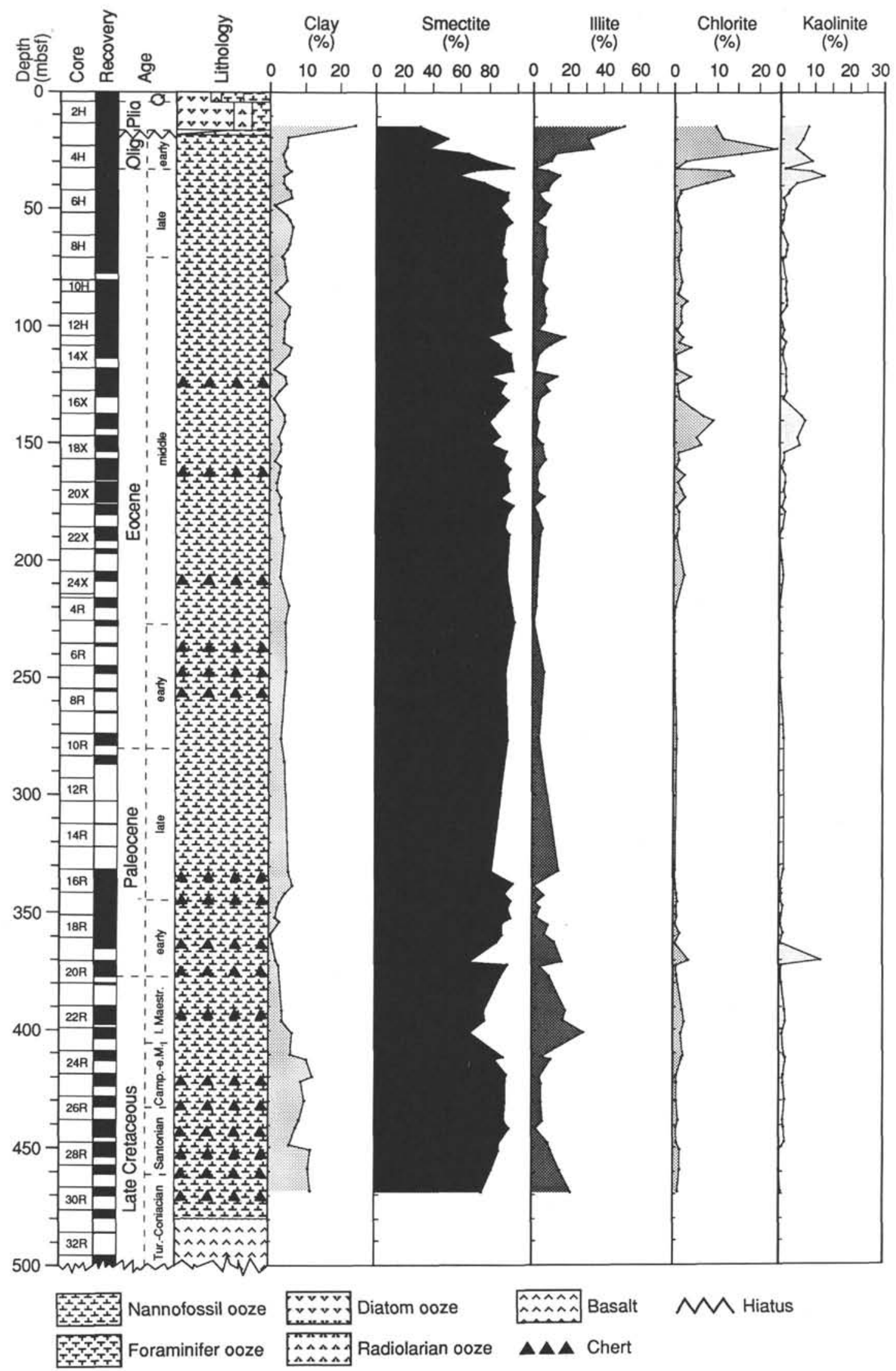

Figure 6. Amount of terrigenous clay (nonbiogenic, $<2 \mu \mathrm{m}$ ) and relative percentage of the individual clay minerals at Holes 738B (Cores $1 \mathrm{H}$ through $24 \mathrm{X}$ ) and $738 \mathrm{C}$ (Cores $4 \mathrm{R}$ through 33R). 

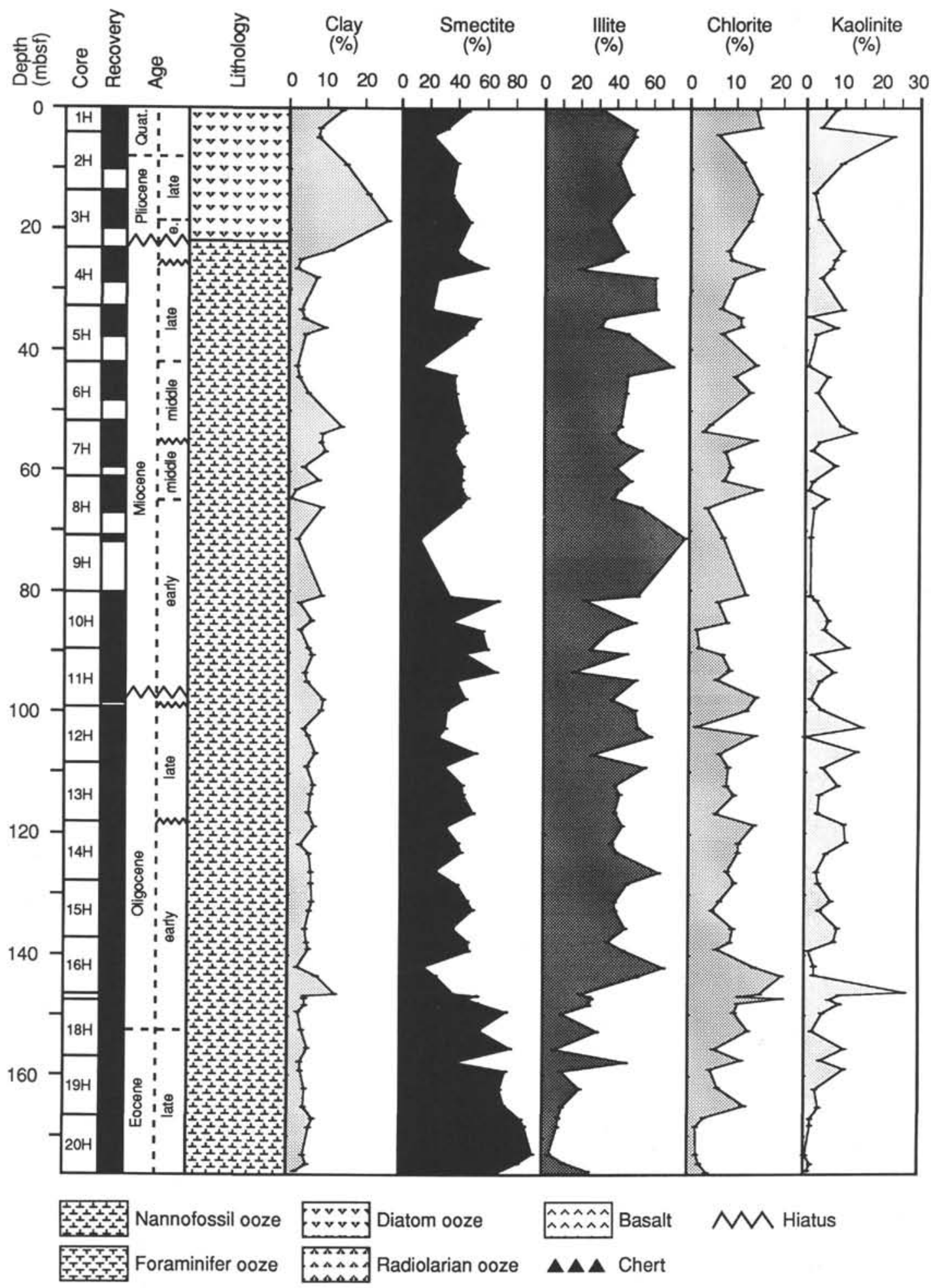

Figure 7. Amount of terrigenous clay (nonbiogenic, $<2 \mu \mathrm{m}$ ) and relative percentage of the individual clay minerals at Hole 744A.

rafted debris. Unfortunately, little is known concerning present and past oceanic circulation systems in the southern Indian Ocean.

At Sites 738 and 744 the intensity of ice rafting, as reflected in the content of gravel and terrigenous sand, strongly fluctuated through time, but correlates between the two sites (Figs. 4 and 5). The first occurrence of coarse terrigenous material, both gravel and sand sized, is recorded from middle Eocene pelagic sediments at Site 738 (Fig. 4), which have an absolute age of 45$42.3 \mathrm{Ma}$. It is assumed that this material was transported by icebergs, which implies that glaciers already had reached the sea by that time. The absolute amount of ice-rafted debris, however, is 
low, compared with present-day conditions. Continental glaciation is therefore not very likely. Some isolated glaciers probably reached the sea while most of the continent was unglacierized.

The next pulse of input of ice-rafted debris that occurred simultaneously at Sites 738 and 744 (Figs. 4 and 5) marks an early Oligocene time interval at about $36 \mathrm{Ma}$. This pulse is much more pronounced than that of middle Eocene time. It correlates with a change in carbonate deposition and clay mineralogy and, therefore, is thought to represent a major intensification of East Antarctic glaciation. Whether this intensification represents a major mountain glaciation with glaciers calving at sea level or the onset of continental glaciation cannot be concluded from the record of ice-rafted debris alone, because of the reasons previously discussed. A joint discussion of all sediment parameters follows.

In late Oligocene to late Miocene time, ice rafting seems to have played a minor role. Gravel is totally absent at Sites 738 and 744, and terrigenous sand is present in trace amounts only (Figs. 4 and 5). Also, the concentration of terrigenous silt is relatively low, but shows slight maxima at the Oligocene/Miocene transition and in the lower part of the middle Miocene. The decrease in coarse ice-rafted debris may be due to less intense glacial activity, to a reduced availability of detrital material after the earliest glaciers had removed all the loose weathering products, or to oceanographic changes.

An intensification of ice-rafting activity occurred in late Miocene time at about $9 \mathrm{Ma}$. Since that time, ice-rafted gravel and sand occur in large amounts at both Sites 738 and 744 (Figs. 4 and 5).

\section{Clay Mineral Assemblages as Climatic Indicators}

Clay minerals in the ocean basins close to continents are mainly derived from land and were formed as a result of various weathering processes, which were ultimately controlled by climate. The clay mineral types and the proportions of the individual clay minerals in marine sediments therefore depend on the climatic conditions on land and on the nature of the source rocks. The distribution of different clay minerals in the presentday oceans reveals a latitudinal zonation that strongly reflects the pedogenic zonation and climatic conditions on the adjacent continental land masses (Biscaye, 1965; Griffin et al., 1968; Lisitzin, 1972; Windom, 1976). Clay mineral assemblages in deepocean sedimentary sequences are, therefore, useful tools for reconstructing the paleoclimate through time. In high latitudes clay minerals are an especially important tool, because climatic variations and erosional processes are pronounced. Investigations of clay mineral assemblages supplement the paleoclimatic information provided by other indicators (Chamley, 1989). For example, coarse-grained ice-rafted debris in marine sediments indicates that the adjacent continent was glacierized at sea level (see the preceding), but special clay mineral assemblages transported by currents may indicate the onset of glacial conditions in the source area and may therefore predate the first ice-rafted debris. Whereas the ice-rafted debris is difficult to interpret in terms of characterizing the intensity of glaciation, the clay sedimentology provides important information on the dominant weathering processes, and thus may assist in distinguishing between local mountain glaciation and continent-wide glaciation.

Chlorite and illite are especially common in the marine sediments of high latitudes (Biscaye, 1965; Griffin et al., 1968; Moriarty, 1977). These clay minerals are mostly detrital, being the products of physical weathering on land or of glacial scouring, particularly of crystalline or metamorphic rocks, such as those that are widespread in East Antarctica (e.g., Ravich et al., 1984). Chlorite is a characteristic mineral from low-grade, chlorite-bearing metamorphic and basic source rocks, whereas illite tends to be derived from more acidic rocks (Griffin et al., 1968).
Chlorite can only form in the marine environment under rather restricted conditions (Griffin et al., 1968). There is no evidence that illite can form in situ in the open marine environment.

Kaolinite cannot form under glacial conditions. High concentrations of this clay mineral are normally restricted to between temperate and tropical regions, where intense chemical weathering, especially of granitic source rocks, and lateritic soil formation occur on land. However, kaolinite occurring in polar regions may be derived from the weathering of older, kaolinitebearing sediments and the erosion of paleosols (Darby, 1975; Chamley, 1989; Hambrey et al., this volume).

Smectite is derived mainly as a result of submarine chemical weathering of volcanic material (e.g., Biscaye, 1965; further references in Kastner, 1981). In contemporary oceans smectite is found mainly in regions where the volcanic activity that provides the source rocks is high, where sedimentation rates resulting in long exposure times for volcanic rocks and ashes are low, and where the input of terrigenous material is low and, therefore, dilution is reduced. However, there is also input of smectite from the continents. Cretaceous and older smectites, especially, are often thought to have originated from subaerial weathering of basic rocks, such as basalts, under humid to arid climatic regimes (Chamley, 1979; Chamley et al., 1984).

\section{Origin of Clay Minerals}

Much of the East Antarctic craton provides large quantities of appropriate source rocks for supplying both illites and chlorites. This area is composed mainly of migmatites and biotitequartz-feldspar gneiss and smaller areas of charnockite. Quartzites, quartz-mica schists, and some ferruginous schists also occur (Trail and McLeod, 1969; Craddock, 1982; Ravich and Fedorov, 1982).

Most, if not all, of the kaolinite found in the sediments at Sites 738 and 744 (Figs. 6 and 7) is assumed to be a recycling product. It is derived as a result of the erosion of old kaolinitebearing sedimentary rocks or soils. The source of the kaolinite may be the Permian Amery Formation or equivalent rocks that may have occupied the Lambert Graben. The Amery Formation crops out at Beaver Lake, just west of the main stream of the Lambert Glacier, close to the present-day coastline. Its extension beneath the ice is not known but is probable. The unit is at least $500 \mathrm{~m}$ thick and is composed of current-bedded feldspathic sandstones, calcareous in part, made up of angular grains of quartz, potash feldspar, and minor plagioclase in a kaolinitic matrix (Trail and McLeod, 1969). At Sites 738 and 744 (Figs. 6 and 7), the coincidence of the first occurrence of larger amounts of kaolinite with a distinct increase in the concentration of the detrital clay minerals illite and chlorite provides further evidence for a detrital source on the Antarctic continent. Found at the Prydz Bay Sites 739 and 742, just in front of the Amery Ice Shelf complex, were even higher kaolinite concentrations of about $60 \%$ in the lower Oligocene sediments and about $20 \%$ in the younger sediments, which also indicate a source in the hinterland (Hambrey et al., this volume).

In several high-latitude settings a correlation between kaolinite and smectite has been found and a common source reconstructed. In Baffin Bay, for example, kaolinite and smectite originated from offshore coastal plain sediments of Mesozoic to Tertiary age, whilst on the margin of Nova Scotia they are derived from Carboniferous to Triassic red beds (Piper and Slatt, 1977). For smectites in sediments drilled in the Southern Ocean during Legs 28, 29, and 113 a continental origin is also assumed (Piper and Pe, 1977; Barker, Kennett, et al., 1988). Evidence of chemical weathering and smectite formation has been reported from a few soils from Antarctica (Claridge, 1965; compilations in Campbell and Claridge, 1987, pp. 130 ff.; Chamley, 1989, pp. $26 \mathrm{ff}$.). A source similar to that of kaolinite is therefore pos- 
sible for the smectite found on the southern Kerguelen Plateau. However, there is no positive correlation between the smectite content and the kaolinite content (Site 744: $r=-0.29$ ), which makes a common source unlikely. The correlation with chlorite is also poor and negative (Site 744: $r=-0.43$ ). A strong negative correlation exists between the illite and smectite concentrations (Site 744: $r=-0.93$ ). This is not surprising, because these two clay minerals occur in similar proportions and together account for $70 \%-90 \%$ of the clay mineral assemblage. A continental source for the smectite in sediments from Site 744 therefore seems unlikely. The smectite is derived instead from submarine chemical alteration of volcanic material. For the older smectite at Site 738, however, a continental source cannot be excluded.

\section{Paleoclimatic Implications}

The clay mineral assemblages recovered from the southern Kerguelen Plateau at Sites 738 and 744 reveal only minor fluctuations in the Cretaceous to Eocene sediments (Figs. 6 and 7). These assemblages are clearly dominated by smectite-type minerals, which account for at least $80 \%$ of the clay minerals. The high smectite content compared with that of the detrital clay minerals illite and chlorite implies that physical weathering processes on the nearby continents played only a limited role. Relatively stable conditions, with chemical weathering under humid conditions dominant, are therefore assumed. Despite the overwhelming dominance of smectites, minor inputs of detrital clay minerals are documented (Fig. 6). They are restricted to the Coniacian to lower Santonian (illite), upper Maestrichtian (illite), lower Paleocene (illite and minor chlorite), and a short period in the middle part of the middle Eocene (chlorite and kaolinite).

The major change in the weathering regime on the Antarctic continent occurred near the Eocene/Oligocene boundary. All four clay minerals-smectite, illite, chlorite, and kaolinite-reveal a distinct shift in their concentration patterns. The smectite concentrations decrease drastically and the concentrations of the detrital clay minerals clearly increase (Figs. 6 and 7).

At Site 738 (Fig. 6) the decrease in smectite content and increase in illite content is in Section 119-738B-5H-7, whereas the increase in chlorite and kaolinite begins upsection, in Section 119-738B-5H-5 (no sample from Section 119-738B-5H-6 has been analyzed so far). Both markers occur in the uppermost Eocene; the first one gives an approximate age of $38.8 \mathrm{Ma}$, the latter one $38.4 \mathrm{Ma}$. The peak minimum and maxima of smectite, illite, chlorite, and kaolinite, respectively, all occur in Section 119-738B-5H-3, which corresponds to about $38.0 \mathrm{Ma}$. The peaks at $38.0 \mathrm{Ma}$, however, indicate a short excursion only, because in Section 119B-738B-4H-7 (37.2 Ma) the former level is reached again. At $37.2 \mathrm{Ma}$ occurs the decrease to persistent lower smectite concentrations and higher illite, chlorite, and kaolinite concentrations. Better age estimates are hampered by the low sedimentation rates at Site 738 and an inadequate paleomagnetic record.

Although the upper Eocene clay mineral composition at Site 744 is dominated by smectite, smectite abundance decreases slightly between the upper Eocene and the lower Oligocene (Fig. 7). A first, short-lived minimum that occurs in Section 119744A-19H-2 (37.5 Ma) probably correlates with Site 738. The sharp kink in the concentration curve occurs in Section 119$744 \mathrm{~A}-18 \mathrm{H}-2$. The illite concentration increases slightly in the uppermost Eocene sediments and abruptly at the point at which the smectite concentration decreases. The distribution pattern of chlorite is somewhat more diffuse. However, the shift in chlorite concentrations seems to start in Section 119-744A-19H-6 (38.3 Ma), in uppermost Eocene sediments. Kaolinite first appears in significant amounts also in Section 119-744A-19H-6. It therefore appears that the change in clay mineral composition at Site 744 begins at about $38.3 \mathrm{Ma}$.

The peak development in the concentration curve for kaolinite occurs in Section 119-744A-16H-7 (146 mbsf), that of chlorite in Section 119-744-16H-5 (143 mbsf), and that of smectite and illite in Section 119-744A-16H-4 (142 mbsf). The corresponding ages are $36.0,35.7$, and $35.5 \mathrm{Ma}$ (Barron et al., this volume).

The preceding discussion reveals that in latest Eocene time, at $38.8-38.3 \mathrm{Ma}$, the clay mineralogy started to change significantly. Before this, the clay mineral assemblages were characterized by the dominance of smectite-type clay minerals and the lack of the detrital clay minerals illite and chlorite, indicating chemical weathering under moderately warm, humid climatic conditions. In younger times, the assemblages were dominated by illite and chlorite, which are indicative of a cooler climate and physical weathering conditions. Thus, cooler, probably glacial conditions established in East Antarctica from about 38.5 Ma resulted in intensive physical weathering.

In Oligocene to recent sediments the clay minerals chlorite, illite, and kaolinite do not reveal changes in their concentration patterns as distinctive as those close to the Eocene/Oligocene boundary, which indicates that the main shift in the weathering regime happened then. It does not necessarily imply that the main shift in paleoclimate occurred at that time. Once the continent was under glaciers, the clay mineral composition of the sediments made available by physical weathering would not have changed significantly in response to a further cooling event. The total amount of detrital clay minerals, however, may react to such a climatic change.

No positive or negative correlation among illite, chlorite, and kaolinite has been recognized. This implies that several source areas influenced the composition of the clay mineral assemblages found at Sites 738 and 744. Complex interactions of primary availability and distribution processes are probably responsible for the concentration of clay minerals in the deep-sea sediments. The data do not allow the different source areas and their fluctuating influence on the total clay mineral assemblages to be defined. However, the sum of the detrital clay minerals illite, chlorite, and kaolinite reflects changes in the intensity of physical weathering, and therefore probably indicates climatic changes. For reasons of simplicity, it is not the sum of detrital clay mineral concentrations but the negatively correlated smectite concentrations that are used for further paleoclimatic interpretations, with high concentrations characteristic of warm climate and reduced input of physical weathering products (Fig. 8).

Following the lower Oligocene minimum in smectite concentrations, the values rise suddenly, but do not reach their former concentrations (Fig. 8). Between the lower Oligocene and the lower part of the lower Miocene, smectite concentrations fluctuate at about $40 \%$, with a slight decreasing trend. They indicate somewhat warmer conditions than in early Oligocene time, but colder conditions than in the rest of Paleogene and Cretaceous time. A climatic optimum in the early Miocene is indicated by maximum Neogene smectite concentrations of about $60 \%$. This maximum dates from about 20.5 to $19.0 \mathrm{Ma}$ (Barron et al., this volume). Another indication of warmer climate is found in the enhanced smectite concentrations within the uppermost Miocene, which are followed by strongly decreasing values indicative of a major cooling phase (Fig. 8).

The smectite concentrations on the southern Kerguelen Plateau reveal essentially the same features as the oxygen isotope curve for planktonic foraminifers in the southwest Pacific (Shackleton and Kennett, 1975; Fig. 8): a decrease in middle Eocene time, a marked drop at the Eocene/Oligocene boundary, an increase after the early Oligocene minimum, relatively constant 


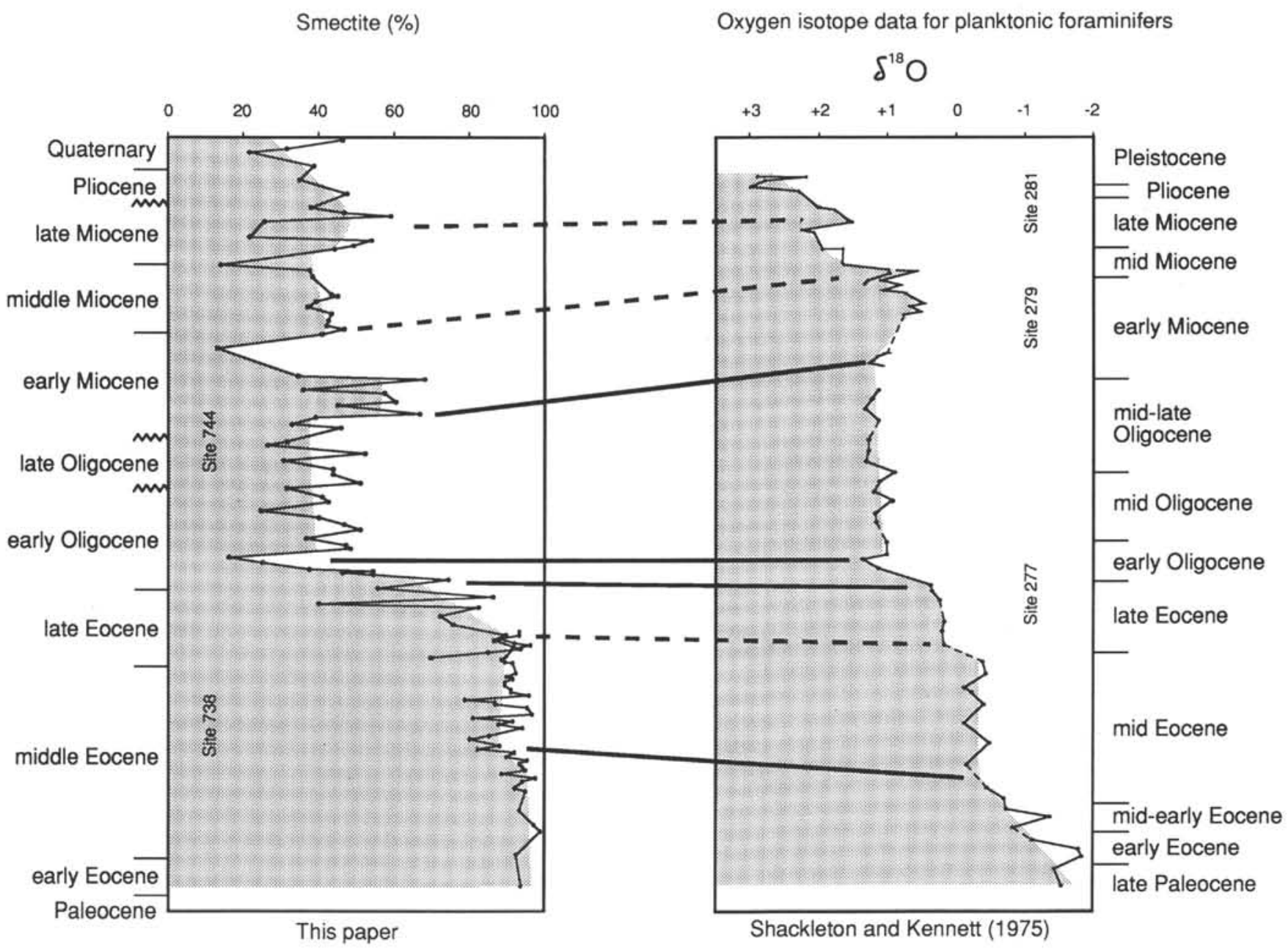

Figure 8. Correlation of the oxygen isotope curve for planktonic foraminifers in the southwest Pacific (Shackleton and Kennett, 1975) and smectite content on the southern Kerguelen Plateau. The generalized trend is shaded.

values with a slight decreasing trend to early early Miocene, a maximum in early Miocene time, and a distinctive decreasing trend in the younger sediments. The correlation between the oxygen isotope curve and the smectite content is striking in Paleocene to early Miocene times, but less convincing in younger sediments. The weaker correlation in younger material is probably due to oceanographic changes connected with the cooling of the Southern Ocean and to plate tectonic evolution. The opening of the Drake Passage as a deep-water pathway probably initiated the development of an intensified circumpolar Antarctic current and thus created a more complicated circulation pattern around Antarctica, which also may have influenced the distribution of clay minerals.

\section{PREGLACIAL CONDITIONS}

In Late Cretaceous time the Antarctic continent reached a central polar position (Smith et al., 1982). Australia was still connected to Antarctica. The Cretaceous Period generally is thought to have been characterized by an equitable, warm, and stable world climate that already had governed most of earlier Mesozoic time. This general configuration did not change much during Late Cretaceous, Paleocene, and early Eocene time (Haq, 1981). Oxygen isotope data confirm the relatively high temperatures postulated from faunal and floral evidence. They further imply low thermal gradients between high and low latitudes and also low thermal gradients between ocean surface and deep wa- ters (Bowen, 1966; Kennett, 1982; Shackleton and Kennett, 1975; Oberhänsli and Hsü, 1986). The presence of barriers to surface and deep water circulation around Antarctica prohibited the generation of a circumpolar circulation, and, therefore, warm equatorial surface currents were able to influence the high southern latitudes and exert a major influence on the global climate and oceanography (Barron and Baldauf, 1989).

Some evidence for Cretaceous glaciation at sea level was presented by Frakes and Francis (1988). They interpreted the occurrence of outsized "exotic blocks" in Lower Cretaceous strata of central Australia to be due to ice rafting. They further concluded that the warm Cretaceous climate allowed at least seasonal periglacial or even glacial conditions in southern high latitudes. Matthews and Poore (1980) also speculated that the buildup of Antarctic ice may date back to the Cretaceous Period. The latest oxygen isotope data obtained from Late Cretaceous fossils from James Ross Island, Antarctica, also seem to indicate the presence of cool polar regions in Late Cretaceous time (Pirrie and Marshall, 1990).

The sedimentological data from southern Kerguelen Plateau Site 738 do not support glacial conditions at sea level in Cretaceous, Paleocene, and early Eocene times. The input of terrigenous material was low and there is no indication of ice rafting. The terrigenous material present is mainly clay sized, which implies transport by suspension or wind. The clay mineral composition is dominated by smectite. The lack of detrital clay miner- 
als indicates that physical weathering processes were of minor importance on the nearby continents. Chemical weathering processes and a warm and humid climate are therefore assumed to have been dominant. The high carbonate concentrations, combined with high bulk-sedimentation rates recorded at Site 738 , and the high primary content of opal that has been diagenetically altered to chert can be regarded as indications of high productivity.

\section{ONSET OF EAST ANTARCTIC GLACIATION}

The oldest isolated gravel and terrigenous sand grains of icerafted origin were detected in upper middle Eocene sediments at Site 738. Their age is $45.0-42.3 \mathrm{Ma}$. These occurrences correlate exactly with slightly enhanced illite concentrations. Chlorite and kaolinite also have short and slight maxima in the upper middle Eocene, but they slightly precede the maxima in ice-rafted material and illite. It is thus obvious that ice had already reached sea level in late middle Eocene time, but the extent of the glaciation is unknown. In comparison with present-day conditions, and in view of the dominance of smectites over detrital clay minerals, it is assumed that in late middle Eocene time glacierization was much less extensive than that of today. Some glaciers probably reached sea level, but much of the main East Antarctic continent was ice free.

Prior to Leg 119, Margolis and Kennett (1970) recorded isolated and probably glacially derived sand grains in lower Eocene and upper middle Eocene sediments from the subantarctic South Pacific Ocean. At least local glacierization in Paleocene-middle Eocene time has been postulated by Birkenmajer (in press) from glaciomarine sediments on King George Island (South Shetland Islands). No evidence for ice rafting during Paleocene and early Eocene time, however, has been found on the Kerguelen Plateau.

According to isotopic data, especially from the Atlantic, Indian, and Southern oceans, a long-term cooling trend began in earliest middle Eocene time at about $52 \mathrm{Ma}$. This trend is marked by several major cooling steps separated by intervals of more stable conditions and occasional warming (Shackleton and Kennett, 1975; Shackleton, 1986; Miller et al., 1987). The surface water temperature in subpolar regions dropped from about $19^{\circ} \mathrm{C}$ in the early Eocene to about $11^{\circ} \mathrm{C}$ in the late Eocene. The bottom waters experienced about the same degree of cooling (Shackleton and Kennett, 1975). A middle Eocene cooling event is also recorded by fossil land plants on the Northern Hemisphere (Wolfe, 1978). This event may also be reflected in the general decrease in carbonate-accumulation rates in the Indian Ocean at $44 \mathrm{Ma}$ (Davies and Worsley, 1981) and a migration of high-latitude planktonic microfossil assemblages toward lower latitudes (Oberhänsli and Hsü, 1986).

A major intensification of glaciation, which probably marks the onset of the continental-scale East Antarctic glaciation, is recorded in sediments of early Oligocene age. All investigated sediment parameters at Sites 738 and 744 document this major event (Figs. 2-7).

The clay mineral assemblages started to change at about 38.5 $\mathrm{Ma}$. Prior to that time, they were dominated by smectite-type minerals and only trace amounts of the detrital clay minerals illite, chlorite, and kaolinite. This assemblage is characteristic of chemical weathering under humid conditions. At $38.5 \mathrm{Ma}$ the smectite concentrations began to decrease steadily while the detrital clay minerals became more important, which indicates that the chemical weathering conditions on East Antarctica were gradually replaced by physical weathering conditions. The peak development in the clay mineral distribution (i.e., minimum smectite concentrations and maximum illite, chlorite, and kaolinite concentrations) found to occur at 36.0-35.5 Ma implies continental rather than mountain glaciation.
A very sharp and intense pulse of ice rafting is recorded at both Sites 738 and 744 in lower Oligocene sediments with an age of $36.0 \mathrm{Ma}$. Early Oligocene ice-rafted debris was also recorded from Leg 113 in the Weddell Sea (Barker, Kennett, et al., 1988). These occurrences further support a major intensification of East Antarctic glaciation at this time. It is interesting to note that this maximum occurs later than the initial change in the clay mineralogy, which is explained by the assumption that the first glacially derived clay minerals were not transported by ice but by suspension, and that it took about $2.5 \mathrm{Ma}$ from the establishment of an East Antarctic Ice Sheet until ice reached sea level.

A distinct and sharp change in carbonate deposition also occurred at Sites 738 and 744 in early Oligocene time. This change correlates with the ice-rafting signal at $36 \mathrm{Ma}$. Prior to this time, carbonate content was relatively high and uniform $(90 \%-$ $95 \%$ ). In Oligocene and younger strata, carbonate concentrations fluctuate from $65 \%$ to $95 \%$. The diminished carbonate concentrations are due to dissolution, probably as a result of the generation of cold and aggressive bottom waters.

Although the sediments recovered from the southern Kerguelen Plateau yielded strong evidence of intense glaciation by early Oligocene time, the dispute of continental vs. mountain glaciation cannot yet be resolved. The most striking evidence for continent-wide glaciation comes from the Prydz Bay Sites 739 and 742 . There, massive diamictites deposited as waterlain tills document a position of the grounding line of the Amery Ice Shelf complex approximately $140 \mathrm{~km}$ north of the edge of the present-day floating ice shelf, which implies a fully established East Antarctic Ice Sheet (Hambrey et al., 1989; this volume). The sediments recovered during the CIROS-1 drilling operation in the Ross Sea strongly support this hypothesis (Barrett, 1989). A continental glaciation by early Oligocene time $(>35 \mathrm{Ma})$ is also postulated based on glaciomarine sediments from King George Island (Gazdzicki, 1989).

Further evidence for the onset of continental glaciation in early Oligocene time comes from oxygen isotope data. The most dramatic Cenozoic decrease in $\delta^{18} \mathrm{O}$ occurred shortly after the Eocene/Oligocene boundary, at about 35.8 Ma (Shackleton and Kennett, 1975; Shackleton, 1986; Miller et al., 1987). The cooling in East Antarctica and the buildup of continental ice that reached sea level are responsible for the cooling of the surface waters of the Southern Ocean and the formation of sea ice. Cold and saline water could descend to a greater depth and thus form cold bottom water. Surface water temperatures dropped from about $11^{\circ}$ to $6^{\circ}-7^{\circ} \mathrm{C}$, and bottom water temperatures dropped from $8^{\circ}-9^{\circ}$ to $5^{\circ} \mathrm{C}$. This cooling of deep ocean waters and surface waters occurred within some 100,000 yr (Shackleton and Kennett, 1975; Shackleton, 1986). Prentice and Matthews (1988) postulated that at least as much ice as today has existed in Antarctica since about $42.5 \mathrm{Ma}$.

\section{OLIGOCENE TO HOLOCENE GLACIAL HISTORY}

The steady northward drift of Australia since late early Eocene/middle Eocene time (Weissel and Hayes, 1972), the northward drift of the Indian plate, and the opening of the Drake Passage allowed the establishment of a circum-Antarctic current by the earliest Oligocene time (Kennett and Shackleton, 1976). This current had an immense influence on the thermal isolation of Antarctica. The cooling of East Antarctica and of the water masses of the Southern Ocean also led to an intensification of oceanic circulation. Sites 738 and 744 are situated within presentday Circumpolar Deep Water, and the several hiatuses clearly indicate that this water mass has had intensified circulation and a more erosive character since Oligocene time. Hiatuses identified in Site 744 sediments span the time intervals 32.0-28.5, 26.5-24.5, 24.0-21.5, 13.5-11.5, 9.0-6.0, and 5.5-4.0 Ma (Bar- 
ron et al., this volume). At Site 738 one large hiatus separates early Oligocene from early late Miocene age sediments, spanning the time interval 35-10 Ma. Further hiatuses comprise the intervals 8.4-6.1 and $>5.8-<4.8 \mathrm{Ma}$. The sedimentary sequence between these hiatuses is probably condensed (Barron, Larsen, et al., 1989).

Following the earliest Oligocene minimum in smectite concentration at $36 \mathrm{Ma}$, which matches the onset of continental glaciation in East Antarctica, the values rose again and retained an almost constant level between about $35 \mathrm{Ma}$ (early Oligocene) and about 20.5 Ma (early Miocene). However, they did not reach their former concentrations. The oxygen isotope data show a similar trend (Shackleton and Kennett, 1975), implying somewhat warmer conditions than in earliest Oligocene time, but colder conditions than in the rest of the Paleogene and Cretaceous time.

The amount of ice-rafted debris recovered at Sites 738 and 744 strongly decreased after its early Oligocene maximum. This could be a result of less intense glaciation. It also could be caused by a lower availability of terrigenous material on the continent. The first glaciers that reached the sea eroded large quantities of soils and loose weathering products derived from both basement rocks and Permian and younger sedimentary strata. Later, all the loose, unconsolidated material was removed and the glaciers had to erode unweathered rocks, and therefore were only able to transport minor amounts of terrigenous material characterized by a smaller grain size. However, ice-rafted debris is documented in all sediments younger than earliest Oligocene by the presence of quartz. Although the quartz is found only in low quantities, it is more abundant than in the Cretaceous to Eocene sediments (Bohrmann and Ehrmann, this volume). The quartz is mainly restricted to the silt fraction, but a few sand-sized grains also occur. The presence of quartz in these sediments indicates that glaciers advanced to the East Antarctic shoreline throughout that time.

The long-term Cenozoic cooling trend was interrupted by an early Miocene warming, as indicated by maximum Neogene smectite concentrations of approximately $60 \%$ and by isotopic data (Shackleton and Kennett, 1975; Margolis et al., 1977). This maximum is followed by a sharp decrease to values of about $40 \%$ in the middle Miocene, suggesting a major cooling phase. A worldwide increase in $\delta^{18} \mathrm{O}$ of both planktonic and benthic foraminifers occurs at the same time.

Following the late early Oligocene to early late Miocene time interval, when ice rafting was of less importance, ice rafting intensified in the late Miocene $(9.0 \mathrm{Ma})$ and reached a maximum between the latest Miocene and the present (5.8-0 Ma). This change in the intensity of ice rafting may indicate an intensification of glaciation, the buildup of the West Antarctic Ice Sheet, or a cooling of the surface water, allowing further offshore transport of the debris by icebergs.

The latest Miocene maximum in ice rafting correlates with a sharp decrease in carbonate deposition and the onset of intense diatom ooze sedimentation. It suggests a pronounced intensification of Antarctic glaciation, combined with a northward expansion of cool surface waters and a northward migration of the Polar Front, and a drastic shoaling of the CCrD and CCD. This transition from nannofossil ooze to diatom ooze is dated at $>6.1 \mathrm{Ma}$ at Site 738 and at $5.8 \mathrm{Ma}$ at Site 744 , and also is recorded in the latest Miocene age sediments at Sites 689 and 690 on the Maud Rise (Barker, Kennett, et al., 1988). From that time on, Sites 738 and 744 have been beneath the high biogenic siliceous productivity zone.

The late Miocene to Holocene changes in ice-rafting activity and the glacial history of East Antarctica have been deduced in more detail from the sediments of Sites 745 and 746 in the Australian-Antarctic Basin (Ehrmann et al., this volume).

\section{ACKNOWLEDGMENTS}

This study was generously supported by Grant Fu 119/15 of the Deutsche Forschungsgemeinschaft. The author is especially grateful to Andreas Mackensen, Michael J. Hambrey, and Martin Melles for fruitful discussions and comments on the manuscript. Anke Hienen, Rita Fröhlking, and Imke Engelbrecht are thanked for technical assistance. The English text was improved by M. J. Hambrey.

This is Contribution No. 293 of the Alfred Wegener Institute for Polar and Marine Research.

\section{REFERENCES}

Aubry, M.-P., Berggren, W. A., Kent, D. V., Flynn, J. J., Klitgord, K. D., Obradovich, J. D., and Prothero, D. R., 1988. Paleogene geochronology: an integrated approach. Paleoceanography, 3:707-742.

Barker, P. F., Kennett, J. P., et al., 1988. Proc. ODP, Init. Repts., 113: College Station, TX (Ocean Drilling Program).

Barrett, P. J. (Ed.), 1989. Antarctic Cenozoic history from the CIROS-1 drillhole, McMurdo Sound. DSIR Bull., 245.

Barron, J. A., and Baldauf, J. G., 1989. Tertiary cooling steps and paleoproductivity as reflected by diatoms and biosiliceous sediments. In Berger, W. H., Smetacek, V. S., and Wefer, G. (Eds.), Productivity of the Oceans: Present and Past. Life Sci. Res. Rep., 44:341-354.

Barron, J. A., and Keller, G., 1982. Widespread Miocene deep-sea hiatuses: coincidence with periods of global cooling. Geology, 10:557581.

Barron, J., Larsen, B., et al., 1989. Proc. ODP, Init. Repts., 119: College Station, TX (Ocean Drilling Program).

Berggren, W. A., Kent, D. V., Flynn, J. J., and Van Couvering, J. A., 1985. Cenozoic geochronology. Geol. Soc. Am. Bull., 96:14071418.

Birkenmajer, K., in press. Tertiary glacial and interglacial deposits, South Shetland Islands, Antarctica: geochronology versus biostratigraphy (a progress report). Bull. Pol. Acad. Sci. Earth Sci.

Biscaye, P. E., 1964. Distinction between kaolinite and chlorite in recent sediments by X-ray diffraction. Am. Miner., 49:1281-1289.

, 1965. Mineralogy and sedimentation of recent deep-sea clay in the Atlantic Ocean and adjacent seas and oceans. Geol. Soc. Am. Bull., 76:803-832.

Blank, R. G., and Margolis, S. V., 1975. Pliocene climatic and glacial history of Antarctica as revealed by southeast Indian Ocean deep-sea cores. Geol. Soc. Am. Bull., 86:1058-1066.

Bornhold, B. D., 1983. Ice-rafted debris in sediments from Leg 71 , southwest Atlantic Ocean. In Ludwig, W. J., Krasheninnikov, V. A., et al., Init. Repts. DSDP, 71: Washington (U.S. Govt. Printing Office), 307-316.

Bowen, R., 1966. Paleotemperature Analysis: Amsterdam (Elsevier).

Campbell, I. B., and Claridge, G.G.C., 1987. Antarctica: Soils, Weathering Processes and Environment: Amsterdam (Elsevier).

Chamley, H., 1979. North Atlantic clay sedimentation and paleoenvironment since the Late Jurassic. In Talwani, M., Hay, W., and Ryan, W.B.F. (Eds.), Deep Drilling Results in the Atlantic Ocean. Am. Geophys. Union, Maurice Ewing Ser., 3:342-361. 1989. Clay Sedimentology: Berlin (Springer).

Chamley, H., Maillot, H., Duée, G., and Robert, C., 1984. Paleoenvironmental history of Walvis Ridge at the Cretaceous-Tertiary transition, from mineralogical and geochemical investigations. In Moore, T. C., Jr., Rabinowitz, P. D., et al., Init. Repts. DSDP, 74: Washington (U.S. Govt. Printing Office), 685-695.

Ciesielski, P. F., Ledbetter, M. T., and Ellwood, B. B., 1982. The development of Antarctic glaciation and the Neogene paleoenvironment of the Maurice Ewing Bank. Mar. Geol., 46:1-51.

Claridge, G.G.C., 1965. The clay mineralogy and chemistry of some soils from the Ross dependency, Antarctica. N.Z. J. Geol. Geophys., 3:186-220.

Craddock, C., 1982. Geological map of Antarctica. In Craddock, C. (Ed.), Antarctic Geoscience: Madison (Univ. Wisconsin Press).

Darby, D. A., 1975. Kaolinite and other clay minerals in Arctic Ocean sediments. J. Sediment. Petrol., 45:272-279.

Davies, T. A., Weser, O. E., Luydendyk, B. P., and Kidd, R. B., 1975. Unconformities in the sediments of the Indian Ocean. Nature, 253: 15-19. 
Davies, T. A., and Worsley, T. R., 1981. Paleoenvironmental implications of oceanic carbonate sedimentation rates. In Warme, J. E., Douglas, R. G., and Winterer, E. L. (Eds.), The Deep-Sea Drilling Project: A Decade of Progress. Soc. Econ. Paleont. Mineral. Spec. Publ., 32:169-179.

Dietrich, G., and Ulrich, J., 1968. Atlas zur Ozeanographie: Mannheim (Bibliographisches Institut).

Drewry, D. J., 1986. Glacial Geological Processes: London (Arnold).

Fisher, R. L., Jantsch, M. Z., and Comer, R. L., 1982. General Bathymetric Chart of the Oceans (GEBCO), Scale 1:10,000.000: Ottawa (Canadian Hydrographic Service), 5.9.

Frakes, L. A., and Francis, J. E., 1988. A guide to Phanerozoic cold polar climates from high-latitude ice rafting in the Cretaceous. Nature, 333:547-549.

Gazdzicki, A., 1989. Planktonic foraminifera from the Oligocene Polonez Cove Formation of King George Island, West Antarctica. Pol. Polar Res., 10:47-55.

Griffin, J. J., Windom, H., and Goldberg, E. D., 1968. The distribution of clay minerals in the world ocean. Deep-Sea Res. Oceanogr. Abstr., 15:433-459.

Grobe, H., 1986. Spätpleistozäne Sedimentationsprozesse am Antarktischen Kontinentalhang vor Kapp Norvegia, 8stliche Weddell See. Repts. Polar Res., Bremerhaven (Alfred Wegener Institute), 27.

Hambrey, M. J., Larsen, B., Ehrmann, W. U., and ODP Leg 119 Shipboard Scientific Party, 1989. Forty million years of Antarctic glacial history yielded by Leg 119 of the Ocean Drilling Program. Polar Rec., 25:99-106.

Haq, B. U., 1981. Paleogene paleoceanography: early Cenozoic oceans revisited. Oceanol. Acta, Proc. 26th Int. Geol. Congr., Geol of Oceans Symp., Paris, 4, Suppl.:71-82.

Hayes, D. E., and Vogel, M., 1981. General Bathymetric Chart of the Oceans (GEBCO), Scale 1:10,000.000: Ottawa (Canadian Hydrographic Service), 5.13.

Hsü, K. J., McKenzie, J. A., Oberhänsli, H., Weissert, H., and Wright, R. C., 1984. South Atlantic Cenozoic paleoceanography. In Hsü, K. J., LaBrecque, J. L., et al., Init. Repts. DSDP, 73: Washington (U.S. Govt. Printing Office), 771-785.

Kastner, M., 1981. Authigenic silicates in sediments: formation and diagenesis. In Emiliani, C. (Ed.), The Sea (vol. 7): New York (Wiley), 915-980.

Kellogg, T. B., and Kellogg, D. E., 1988. Antarctic cryogenic sediments: biotic and inorganic facies of ice shelf and marine-based ice sheet environments. Palaeogeogr., Palaeoclimatol., Palaeoecol., 67:5174.

Kennett, J. P., 1982. Marine Geology: London (Prentice Hall).

Kennett, J. P., and Shackleton, N. J., 1976. Oxygen isotopic evidence for the development of the psychrosphere $38 \mathrm{Myr}$ ago. Nature, 260: 513-515.

Kolla, V., Bé, A.W.H., and Biscaye, P. E., 1976. Calcium carbonate distribution in the surface sediments of the Indian Ocean. J. Geophys. Res., 81:2605-2616.

Lange, H., 1982. Distribution of chlorite and kaolinite in eastern Atlantic sediments off North Africa. Sedimentology, 29:427-432.

Lisitzin, A. P., 1972. Sedimentation in the World Ocean, with Emphasis on the Nature, Distribution and Behavior of Marine Suspensions. Soc. Econ. Paleontol. Mineral Spec. Publ., 17.

Mackensen, A., Barrera, E., and Hubberten, H.-W., in press. Neogene circulation in the southern Indian Ocean: evidence from benthic foraminiferal assemblages, carbonate, and stable isotopes (ODP Site 751). In Schlich, R., Wise, W. S., et al., Proc. ODP, Sci. Results, 120: College Station, TX (Ocean Drilling Program).

Margolis, S. V., and Kennett, J. P., 1970. Antarctic glaciation during the Tertiary recorded in sub-Antarctic deep-sea cores. Science, 170: 1085-1087.
Margolis, S. V., Kroopnick, P. M., and Goodney, D. E., 1977. Cenozoic and late Mesozoic paleoceanography and paleoglacial history recorded in circum-Antarctic deep-sea sediments. Mar. Geol., 25: 131-147.

Matthews, R. K., and Poore, R. Z., 1980. Tertiary $\delta^{18} \mathrm{O}$ record and glacioeustatic sea-level fluctuations. Geology, 8:501-504.

Miller, K. G., Fairbanks, R. G., and Mountain, G. S., 1987. Tertiary oxygen isotope synthesis, sea level history, and continental margin erosion. Paleoceanography, 2:1-19.

Moriarty, K. C., 1977. Clay minerals in southeast Indian Ocean sediments, transport mechanisms and depositional environments. Mar. Geol., 25:149-174.

Oberhänsli, H., and Hsü, K. J., 1986. Paleocene-Eocene paleoceanography. In Hsü, K.J. (Ed.), Mesozoic and Cenozoic Oceans: Int. Lithosphere Program, Geodynamics Series, 15:85-100.

Piper, D.J.W., and Pe, G. G., 1977. Cenozoic clay mineralogy from D.S.D.P. holes on the continental margin of the Australia-New Zealand sector of Antarctica. N.Z. J. Geol. Geophys., 20:905-917.

Piper, D.J.W., and Slatt, R. M., 1977. Late Quaternary clay mineral distribution on the eastern continental margin of Canada. Geol. Soc. Am. Bull., 88:267-272.

Pirrie, D., and Marshall, J. D., 1990. High-paleolatitude Late Cretaceous paleotemperatures: new data from James Ross Island, Antarctica. Geology, 18:31-34.

Prentice, M. L., and Matthews, R. K., 1988. Cenozoic ice-volume history: development of a composite oxygen isotope record. Geology, 16:963-966.

Ravich, M. G., and Fedorov, L. V., 1982. Geologic structure of MacRobertson Land and Princess Elizabeth Land, East Antarctica. In Craddock, C. (Ed.): Antarctic Geoscience: Madison (Univ. Wisconsin Press), 499-504.

Ravich, M. G., Solov'ev, D. S., and Fedorov, L. V., 1984. Geological Structure of Mac. Robertson Land (East Antarctica): New Delhi (Amerind Publishing). (Translation from 1978 Russian text)

Shackleton, N. J., 1986. Paleogene stable isotope events. Palaeogeogr., Palaeoclimatol., Palaeoecol., 57:91-101.

Shackleton, N. J., and Kennett, J. P., 1975. Paleotemperature history of the Cenozoic and the initiation of Antarctic glaciation: oxygen and carbon isotope analyses in DSDP Sites 277, 279, and 281. In Kennett, J. P., Houtz, R. E., et al., Init. Repts. DSDP, 29: Washington (U.S. Govt. Printing Office), 743-755.

Smith, A. G., Hurley, A. M., and Briden, J. C., 1982. Paläokontinentale Weltkarten des Phanerozoikums: Stuttgart (Enke).

Trail, D. S., and McLeod, I. R., 1969. Geology of the Lambert Glacier region. In Craddock, C. (Ed.), Geologic Maps of Antarctica. Am. Geogr. Soc., Antarctic Map Folio Ser., Plate 11.

Van Andel, T. H., 1975. Mesozoic/Cenozoic calcite compensation depth and the global distribution of calcareous sediments. Earth Planet. Sci. Lett., 26:187-194.

Weissel, J. K., and Hayes, D. E., 1972. Magnetic anomalies in the southeast Indian Ocean. In Hayes, D. E. (Ed.), Antarctic Oceanology II: the Australian-New Zealand Sector. Antarct. Res. Ser., 19: $165-196$.

Whitworth, T., III, 1988. The Antarctic Circumpolar Current. Oceanus, 31:53-58.

Windom, H. L., 1976. Lithogenous material in marine sediments. In Riley, J. P., and Chester, R. (Eds.), Chemical Oceanography (vol. 5): New York (Academic Press), 103-135.

Wolfe, J. A., 1978. A paleobotanical interpretation of Tertiary climates in the Northern Hemisphere. Am. Sci., 66:694-703.

Date of initial receipt: 19 December 1989

Date of acceptance: 10 April 1990

Ms 119B-121 
APPENDIX TABLE 1.

Sediment Composition from Holes 738B, 738C, and 744A

All data are given in weight percent of the bulk sediment. Further carbonate concentrations for Holes 738B and 738C are given in Appendix Table 2 and by Barron, Larsen, et al. (1989).

\begin{tabular}{|c|c|c|c|c|c|}
\hline $\begin{array}{l}\text { Core, section, } \\
\text { interval }(\mathrm{cm})\end{array}$ & $\begin{array}{l}\text { Depth } \\
\text { (mbsf) }\end{array}$ & $\begin{array}{c}\text { Organic } \\
\text { carbon } \\
(\%)\end{array}$ & $\begin{array}{c}\text { Carbonate } \\
(\%)\end{array}$ & $\begin{array}{c}\text { Opal } \\
(\%)\end{array}$ & $\begin{array}{c}\text { Nonbiogenic } \\
(\%)\end{array}$ \\
\hline \multicolumn{6}{|l|}{ 119-738B- } \\
\hline $3 \mathrm{H}-1,125-129$ & 14.75 & & 0.00 & 38.98 & 61.02 \\
\hline $3 \mathrm{H}-5,48-52$ & 19.98 & & 87.30 & 6.24 & 6.46 \\
\hline $4 \mathrm{H}-1,110-114$ & 24.06 & & 88.89 & 5.89 & 5.22 \\
\hline $4 \mathrm{H}-3,48-52$ & 26.35 & & 92.29 & 3.76 & 3.95 \\
\hline $4 \mathrm{H}-5,78-82$ & 29.52 & & 92.76 & 2.67 & 4.57 \\
\hline $4 \mathrm{H}-7,30-34$ & 31.94 & & 90.46 & 4.64 & 4.90 \\
\hline $5 \mathrm{H}-1,100-104$ & 33.46 & & 89.88 & 3.81 & 6.31 \\
\hline $5 \mathrm{H}-3,48-52$ & 35.85 & & 89.20 & 6.51 & 4.29 \\
\hline $5 \mathrm{H}-5,48-52$ & 38.73 & & 93.62 & 2.18 & 4.20 \\
\hline $5 \mathrm{H}-7,30-34$ & 41.44 & & 94.05 & 0.71 & 5.24 \\
\hline $6 \mathrm{H}-1,48-52$ & 42.48 & & 93.12 & 0.56 & 6.32 \\
\hline $6 \mathrm{H}-3,48-52$ & 45.48 & & 92.12 & 1.16 & 6.72 \\
\hline $6 \mathrm{H}-5,48-52$ & 48.48 & & 98.11 & 0.49 & 1.40 \\
\hline $7 \mathrm{H}-1,100-104$ & 52.47 & & 94.05 & 1.02 & 4.93 \\
\hline $7 \mathrm{H}-3,48-52$ & 54.85 & & 92.70 & 1.49 & 5.81 \\
\hline $7 \mathrm{H}-5,48-52$ & 57.79 & & 90.68 & 2.07 & 7.25 \\
\hline $8 \mathrm{H}-3,48-52$ & 64.35 & & 92.50 & 0.61 & 6.89 \\
\hline $8 \mathrm{H}-5,48-52$ & 67.29 & & 93.49 & 0.71 & 5.80 \\
\hline $8 \mathrm{H}-7,30-34$ & 70.03 & & 94.95 & 1.14 & 3.91 \\
\hline $9 \mathrm{H}-1,80-84$ & 71.30 & & 93.57 & 0.87 & 5.56 \\
\hline $9 \mathrm{H}-3,48-52$ & 73.98 & & 94.09 & 0.51 & 5.40 \\
\hline $10 \mathrm{H}-1,48-52$ & 80.48 & & 94.05 & 0.32 & 5.63 \\
\hline $10 \mathrm{H}-3,48-52$ & 83.48 & & 95.37 & 0.54 & 4.09 \\
\hline $11 \mathrm{H}-1,48-52$ & 85.48 & & 97.48 & 0.50 & 2.02 \\
\hline $11 \mathrm{H}-5,48-52$ & 91.48 & & 93.33 & 0.80 & 5.87 \\
\hline $12 \mathrm{H}-1,48-52$ & 94.98 & & 91.85 & 2.54 & 5.61 \\
\hline $12 \mathrm{H}-3,48-52$ & 97.98 & & 94.20 & 1.00 & 4.80 \\
\hline $12 \mathrm{H}-5,48-52$ & 100.98 & & 94.93 & 0.78 & 4.29 \\
\hline $13 \mathrm{H}-1,48-52$ & 104.47 & & 93.65 & 1.58 & 4.77 \\
\hline $13 \mathrm{H}-3,48-52$ & 107.17 & & 92.06 & 3.74 & 4.20 \\
\hline $14 X-1,48-52$ & 108.68 & & 88.42 & 4.57 & 7.01 \\
\hline $14 X-3,48-52$ & 111.68 & & 91.22 & 2.64 & 6.14 \\
\hline $15 X-1,72-76$ & 118.52 & & 98.16 & 0.53 & 1.31 \\
\hline $15 X-3,48-52$ & 121.28 & & 93.19 & 2.29 & 4.52 \\
\hline $15 X-5,48-52$ & 124.28 & & 93.52 & 1.07 & 5.41 \\
\hline $16 \mathrm{X}-1,16-20$ & 127.66 & & 94.80 & 1.84 & 3.36 \\
\hline $16 \times-3,30-34$ & 130.80 & & 98.17 & 0.58 & 1.25 \\
\hline $17 X-1,60-64$ & 137.80 & & 91.55 & 3.97 & 4.48 \\
\hline $17 X-3,48-52$ & 140.68 & & 91.07 & 3.95 & 4.98 \\
\hline $18 X-1,48-52$ & 147.28 & & 94.55 & 2.35 & 3.10 \\
\hline $18 X-3,48-52$ & 150.28 & & 93.39 & 2.63 & 3.98 \\
\hline $18 X-5,48-52$ & 153.28 & & 96.08 & 0.50 & 3.42 \\
\hline $19 X-1,42-46$ & 156.92 & & 97.92 & 0.24 & 1.84 \\
\hline $19 X-3,46-50$ & 159.96 & & 95.80 & 0.58 & 3.62 \\
\hline $19 X-5,48-52$ & 162.98 & & 96.25 & 0.27 & 3.48 \\
\hline $20 X-1,48-52$ & 166.68 & & 96.91 & 0.28 & 2.81 \\
\hline $20 X-3,48-52$ & 169.68 & & 96.73 & 0.32 & 2.95 \\
\hline $20 X-5,48-52$ & 172.68 & & 95.20 & 1.32 & 3.48 \\
\hline $21 X-2,48-52$ & 176.28 & & 95.81 & 0.52 & 3.67 \\
\hline $21 X-3,48-52$ & 179.26 & & 95.80 & 0.35 & 3.85 \\
\hline $22 \times-1,48-52$ & 185.88 & & 94.90 & 1.28 & 3.82 \\
\hline $22 \times-3,48-52$ & 188.88 & & 94.95 & 0.62 & 4.43 \\
\hline $24 X-2,48-52$ & 206.58 & & 95.32 & 0.91 & 3.77 \\
\hline \multicolumn{6}{|l|}{$119-738 \mathrm{C}$ - } \\
\hline $4 \mathrm{R}-3,48-52$ & 219.38 & & 93.10 & 0.70 & 6.20 \\
\hline $5 R-1,46-50$ & 226.06 & & 94.25 & 0.82 & 4.93 \\
\hline $7 \mathrm{R}-2,74-76$ & 247.04 & & 93.60 & 1.11 & 5.29 \\
\hline $10 R-2,36-38$ & 275.66 & & 92.20 & 3.92 & 3.88 \\
\hline $11 R-3,10-12$ & 286.50 & & 92.43 & 2.14 & 5.43 \\
\hline $16 \mathrm{R}-1,48-52$ & 332.08 & & 92.54 & 1.30 & 6.16 \\
\hline $16 R-5,42-44$ & 338.02 & & 91.17 & 1.68 & 7.15 \\
\hline $17 \mathrm{R}-1,58-60$ & 341.86 & & 92.87 & 2.39 & 4.74 \\
\hline $17 \mathrm{R}-3,112-114$ & 345.24 & & 94.83 & 0.55 & 4.62 \\
\hline $17 R-5,56-60$ & 347.58 & & 96.60 & 0.38 & 3.02 \\
\hline $18 \mathrm{R}-1,70-74$ & 351.60 & & 97.14 & 0.61 & 2.25 \\
\hline $18 \mathrm{R}-3,50-54$ & 354.40 & & 95.61 & 1.01 & 3.38 \\
\hline $18 \mathrm{R}-6,48-52$ & 358.88 & & 99.26 & 0.19 & 0.55 \\
\hline $19 \mathrm{R}-2,70-74$ & 362.70 & & 98.38 & 0.48 & 1.14 \\
\hline $20 \mathrm{R}-1,20-24$ & 370.40 & & 94.79 & 2.89 & 2.32 \\
\hline
\end{tabular}

Appendix Table 1 (continued).

\begin{tabular}{cccccc}
\hline $\begin{array}{c}\text { Core, section, } \\
\text { interval (cm) }\end{array}$ & $\begin{array}{c}\text { Depth } \\
\text { (mbsf) }\end{array}$ & $\begin{array}{c}\text { Organic } \\
\text { carbon } \\
(\%)\end{array}$ & $\begin{array}{c}\text { Carbonate } \\
(\%)\end{array}$ & $\begin{array}{c}\text { Opal } \\
(\%)\end{array}$ & $\begin{array}{c}\text { Nonbiogenic } \\
(\%)\end{array}$ \\
\hline 119-738C-(Cont.) & & & & & \\
20R-2, 50-54 & 372.20 & & 96.14 & 0.83 & 3.03 \\
22R-2, 62-65 & 391.72 & 94.29 & 1.13 & 4.58 \\
22R-5, 51-53 & 396.11 & 94.95 & 0.59 & 4.46 \\
23R-2, 47-49 & 401.17 & 90.77 & 1.27 & 7.96 \\
24R-2, 60-62 & 411.00 & 86.49 & 6.99 & 6.52 \\
24R-3, 50-52 & 412.40 & 83.12 & 5.56 & 11.32 \\
25R-1, 64-66 & 419.24 & 85.22 & 1.13 & 13.65 \\
25R-3, 72-74 & 422.32 & 88.30 & 0.24 & 11.46 \\
26R-2, 54-56 & 430.24 & 87.79 & 1.27 & 10.94 \\
27R-1, 49-51 & 438.39 & 89.10 & 1.24 & 9.66 \\
27R-3, 49-51 & 441.39 & 91.57 & 0.23 & 8.20 \\
28R-1, 55-57 & 448.15 & 92.95 & 0.51 & 6.54 \\
28R-3, 48-50 & 451.08 & 86.63 & 0.49 & 12.88 \\
29R-2, 48-50 & 459.18 & 84.62 & 2.83 & 12.55 \\
30R-2, 48-50 & 468.58 & 84.61 & 3.02 & 12.37
\end{tabular}

119-744A-

\begin{tabular}{|c|c|c|c|c|c|}
\hline $1 \mathrm{H}-1,49-51$ & 0.49 & 0.16 & 29.82 & 51.66 & 18.52 \\
\hline $1 \mathrm{H}-3,49-51$ & 3.49 & 0.22 & 60.96 & 27.05 & 11.99 \\
\hline $2 \mathrm{H}-1,49-51$ & 4.69 & 0.25 & 62.69 & 26.76 & 10.55 \\
\hline $2 \mathrm{H}-4,49-51$ & 9.19 & 0.04 & 32.57 & 46.81 & 20.62 \\
\hline $3 \mathrm{H}-1,49-51$ & 14.19 & 0.03 & 29.01 & 26.89 & 44.10 \\
\hline $3 \mathrm{H}-4,49-51$ & 18.69 & 0.00 & 3.91 & 57.64 & 38.45 \\
\hline $4 \mathrm{H}-1,44-46$ & 23.64 & 0.00 & 69.87 & 13.12 & 17.01 \\
\hline $4 \mathrm{H}-2,46-50$ & 25.16 & & 89.86 & 6.81 & 3.33 \\
\hline $4 \mathrm{H}-3,40-44$ & 26.60 & & 91.01 & 6.29 & 2.70 \\
\hline $4 \mathrm{H}-4,45-47$ & 28.15 & 0.08 & 81.51 & 10.91 & 7.58 \\
\hline $5 \mathrm{H}-1,49-50$ & 33.19 & 0.00 & 91.95 & 4.52 & 3.53 \\
\hline $5 \mathrm{H}-2,40-44$ & 34.60 & & 81.60 & 13.67 & 4.73 \\
\hline $5 \mathrm{H}-3,47-49$ & 36.17 & 0.23 & 72.75 & 17.54 & 9.71 \\
\hline $5 \mathrm{H}-4,12-15$ & 37.32 & & 73.43 & 21.60 & 4.97 \\
\hline $6 \mathrm{H}-1,49-51$ & 42.69 & 0.16 & 89.76 & 8.02 & 2.22 \\
\hline $6 \mathrm{H}-2,60-64$ & 44.30 & & 86.44 & 10.66 & 2.90 \\
\hline $6 \mathrm{H}-3,46-50$ & 45.66 & & 95.05 & 3.16 & 1.79 \\
\hline $6 \mathrm{H}-4,49-51$ & 47.19 & 0.11 & 91.38 & 3.42 & 5.20 \\
\hline $7 \mathrm{H}-1,81-83$ & 52.51 & 0.01 & 68.04 & 15.43 & 16.53 \\
\hline $7 \mathrm{H}-2,46-50$ & 53.66 & & 82.87 & 6.03 & 11.10 \\
\hline $7 \mathrm{H}-3,46-50$ & 55.16 & & 79.73 & 8.98 & 11.29 \\
\hline $7 \mathrm{H}-4,49-51$ & 56.69 & 0.26 & 77.47 & 10.51 & 12.02 \\
\hline $7 \mathrm{H}-6,20-24$ & 59.40 & & 93.13 & 2.01 & 4.86 \\
\hline $8 \mathrm{H}-1,49-51$ & 61.69 & 0.00 & 82.42 & 8.51 & 9.07 \\
\hline $8 \mathrm{H}-2,46-50$ & 63.16 & & 78.32 & 14.87 & 6.81 \\
\hline $8 \mathrm{H}-3,46-50$ & 64.66 & & 82.24 & 9.26 & 8.50 \\
\hline $8 \mathrm{H}-4,49-51$ & 66.19 & 0.00 & 84.00 & 5.82 & 10.18 \\
\hline $9 \mathrm{H}-1,49-51$ & 71.19 & 0.00 & 93.45 & 3.93 & 2.62 \\
\hline $10 \mathrm{H}-1,44-46$ & 80.62 & 0.01 & 79.71 & 10.29 & 10.00 \\
\hline $10 \mathrm{H}-2,46-50$ & 81.60 & & 90.15 & 6.48 & 3.37 \\
\hline $10 \mathrm{H}-4,44-46$ & 84.95 & 0.00 & 88.22 & 5.03 & 6.75 \\
\hline $10 \mathrm{H}-5,46-50$ & 86.41 & & 92.93 & 3.54 & 3.53 \\
\hline $10 \mathrm{H}-7,48-52$ & 89.32 & & 90.52 & 3.27 & 6.21 \\
\hline $11 \mathrm{H}-1,49-51$ & 90.19 & 0.23 & 88.05 & 5.13 & 6.82 \\
\hline $11 \mathrm{H}-3,48-52$ & 93.18 & & 89.03 & 5.40 & 5.57 \\
\hline $11 \mathrm{H}-4,49-51$ & 94.69 & 0.00 & 90.15 & 4.05 & 5.80 \\
\hline $11 \mathrm{H}-6,48-52$ & 97.68 & & 83.18 & 5.21 & 11.61 \\
\hline $12 \mathrm{H}-1,49-51$ & 99.67 & 0.04 & 84.30 & 5.31 & 10.39 \\
\hline $12 \mathrm{H}-3,48-52$ & 102.55 & & 89.76 & 5.23 & 5.01 \\
\hline $12 \mathrm{H}-4,49-51$ & 104.00 & 0.00 & 88.04 & 5.59 & 6.37 \\
\hline $12 \mathrm{H}-6,46-50$ & 106.85 & & 89.47 & 2.00 & 8.53 \\
\hline $13 \mathrm{H}-1,49-51$ & 109.19 & 0.00 & 91.79 & 2.51 & 5.70 \\
\hline $13 \mathrm{H}-3,48-52$ & 112.15 & & 89.15 & 3.05 & 7.80 \\
\hline $13 \mathrm{H}-4,49-51$ & 113.64 & 0.00 & 89.59 & 3.31 & 7.10 \\
\hline $13 \mathrm{H}-6,46-50$ & 116.58 & & 91.19 & 2.59 & 6.22 \\
\hline $14 \mathrm{H}-1,49-51$ & 118.69 & 0.00 & 87.93 & 3.61 & 8.46 \\
\hline $14 \mathrm{H}-3,46-50$ & 121.66 & & 94.75 & 1.81 & 3.44 \\
\hline $14 \mathrm{H}-4,49-51$ & 123.19 & 0.16 & 91.11 & 2.74 & 6.15 \\
\hline $14 \mathrm{H}-6,46-50$ & 126.16 & & 88.65 & 3.88 & 7.47 \\
\hline $15 \mathrm{H}-1,49-51$ & 128.18 & 0.00 & 87.25 & 5.97 & 6.78 \\
\hline $15 \mathrm{H}-3,46-50$ & 131.06 & & 82.74 & 9.99 & 7.27 \\
\hline $15 \mathrm{H}-4,49-51$ & 132.54 & 0.00 & 78.69 & 15.25 & 6.06 \\
\hline $15 \mathrm{H}-6,46-50$ & 135.43 & & 88.96 & 6.03 & 5.01 \\
\hline $16 \mathrm{H}-1,49-51$ & 137.67 & 0.00 & 84.82 & 9.72 & 5.46 \\
\hline $16 \mathrm{H}-2,46-50$ & 139.09 & & 87.14 & 6.72 & 6.14 \\
\hline $16 \mathrm{H}-4,49-51$ & $142: 00$ & 0.09 & 77.82 & 19.35 & 2.83 \\
\hline $16 \mathrm{H}-5,46-50$ & 143.41 & & 82.01 & 9.78 & 8.21 \\
\hline $16 \mathrm{H}-7,47-49$ & 146.31 & 0.00 & 61.26 & 11.28 & 27.46 \\
\hline
\end{tabular}


Appendix Table 1 (continued).

\begin{tabular}{llcccc}
\hline $\begin{array}{l}\text { Core, section, } \\
\text { interval (cm) }\end{array}$ & $\begin{array}{c}\text { Depth } \\
\text { (mbsf) }\end{array}$ & $\begin{array}{c}\text { Organic } \\
\text { carbon } \\
(\%)\end{array}$ & $\begin{array}{c}\text { Carbonate } \\
(\%)\end{array}$ & $\begin{array}{c}\text { Opal } \\
(\%)\end{array}$ & $\begin{array}{c}\text { Nonbiogenic } \\
(\%)\end{array}$ \\
\hline $119-744 \mathrm{~A}-($ Cont.) & & & & & \\
& & & & & \\
$17 \mathrm{H}-1,12-14$ & 146.82 & 0.00 & 91.54 & 3.74 & 4.72 \\
$17 \mathrm{H}-\mathrm{CC}, 12-14$ & 147.29 & 0.18 & 90.00 & 4.92 & 5.08 \\
$18 \mathrm{H}-1,49-51$ & 148.08 & 0.00 & 91.82 & 3.32 & 4.86 \\
$18 \mathrm{H}-2,46-50$ & 149.52 & & 94.60 & 2.28 & 3.12 \\
$18 \mathrm{H}-4,49-51$ & 152.49 & 0.25 & 91.55 & 4.56 & 3.89 \\
$18 \mathrm{H}-6,46-50$ & 155.40 & & 92.11 & 2.23 & 5.66 \\
$19 \mathrm{H}-1,49-51$ & 157.59 & 0.07 & 93.78 & 2.82 & 3.40 \\
$19 \mathrm{H}-2,46-50$ & 159.06 & & 95.00 & 1.34 & 3.66 \\
$19 \mathrm{H}-4,49-51$ & 162.09 & 0.13 & 91.58 & 3.81 & 4.61 \\
$19 \mathrm{H}-6,46-50$ & 165.06 & & 90.78 & 4.54 & 4.68 \\
$20 \mathrm{H}-1,49-51$ & 167.00 & & 88.60 & 3.90 & 7.50 \\
$20 \mathrm{H}-2,26-30$ & 168.29 & & 92.49 & 1.39 & 6.12 \\
$20 \mathrm{H}-2,130-134$ & 169.29 & & 95.65 & 0.69 & 3.66 \\
$20 \mathrm{H}-3,49-51$ & 169.96 & 0.03 & 94.07 & 1.29 & 4.64 \\
$20 \mathrm{H}-5,46-50$ & 172.81 & & 94.61 & 0.90 & 4.49 \\
$20 \mathrm{H}-6,49-51$ & 174.28 & 0.03 & 93.45 & 1.24 & 5.31 \\
$20 \mathrm{H}-7,46-50$ & 175.70 & & 96.89 & 0.76 & 2.35 \\
\hline
\end{tabular}

APPENDIX TABLE 2.

Additional Carbonate Concentrations of Samples from Holes 738B and $738 \mathrm{C}$

\begin{tabular}{lrr}
\hline $\begin{array}{l}\text { Core, section, } \\
\text { interval (cm) }\end{array}$ & $\begin{array}{r}\text { Depth } \\
\text { (mbsf) }\end{array}$ & $\begin{array}{c}\text { Carbonate } \\
(\%)\end{array}$ \\
\hline $119-738 \mathrm{~B}-$ & & \\
& & \\
1H-1, 48-50 & 0.48 & 63.99 \\
$1 \mathrm{H}-3,48-50$ & 3.45 & 71.64 \\
$2 \mathrm{H}-2,48-50$ & 5.92 & 52.00 \\
$2 \mathrm{H}-4,48-50$ & 8.83 & 39.77 \\
$2 \mathrm{H}-6,48-50$ & 11.75 & 2.51 \\
$3 \mathrm{H}-2,58-60$ & 15.58 & 0.91 \\
$3 \mathrm{H}-3,58-60$ & 17.08 & 59.04 \\
$3 \mathrm{H}-4,58-60$ & 18.58 & 86.66 \\
$4 \mathrm{H}-2,48-50$ & 24.90 & 89.37 \\
$4 \mathrm{H}-4,48-50$ & 27.79 & 95.40 \\
$4 \mathrm{H}-6,48-50$ & 30.67 & 92.85 \\
$5 \mathrm{H}-2,48-50$ & 34.40 & 92.65 \\
$5 \mathrm{H}-4,48-50$ & 37.29 & 92.49 \\
$5 \mathrm{H}-6,48-50$ & 40.17 & 93.38 \\
$6 \mathrm{H}-2,48-50$ & 44.01 & 93.77 \\
$6 \mathrm{H}-4,48-50$ & 46.53 & 96.00 \\
$6 \mathrm{H}-6,48-50$ & 49.53 & 94.82 \\
$7 \mathrm{H}-2,48-50$ & 53.42 & 95.05 \\
$7 \mathrm{H}-4,48-50$ & 56.33 & 93.50 \\
$7 \mathrm{H}-6,48-50$ & 59.25 & 96.22 \\
$8 \mathrm{H}-2,48-50$ & 62.92 & 94.94 \\
$8 \mathrm{H}-4,48-50$ & 65.83 & 95.99 \\
$8 \mathrm{H}-6,48-50$ & 68.75 & 95.18 \\
$9 \mathrm{H}-2,48-50$ & 72.48 & 95.85 \\
$9 \mathrm{H}-4,48-50$ & 75.48 & 95.84 \\
$10 \mathrm{H}-2,48-50$ & 81.98 & 95.38 \\
$11 \mathrm{H}-2,48-50$ & 86.98 & 93.99 \\
$11 \mathrm{H}-4,48-50$ & 89.98 & 94.25 \\
$11 \mathrm{H}-6,48-50$ & 92.98 & 93.45 \\
$12 \mathrm{H}-2,48-50$ & 96.48 & 99.21 \\
$12 \mathrm{H}-4,48-50$ & 99.48 & 95.72 \\
$12 \mathrm{H}-6,48-50$ & 102.48 & 93.85 \\
$13 \mathrm{H}-2,48-50$ & 105.96 & 94.05 \\
$14 \mathrm{X}-2,47-49$ & 110.17 & 94.36 \\
$14 \mathrm{X}-4,46-48$ & 113.16 & 94.19 \\
& & \\
\hline
\end{tabular}

Appendix Table 2 (continued).

\begin{tabular}{ccc}
\hline $\begin{array}{c}\text { Core, section, } \\
\text { interval (cm) }\end{array}$ & $\begin{array}{c}\text { Depth } \\
\text { (mbsf) }\end{array}$ & $\begin{array}{c}\text { Carbonate } \\
(\%)\end{array}$ \\
\hline $119-738 \mathrm{~B}-($ Cont.) & & \\
& & \\
$15 \mathrm{X}-2,48-50$ & 119.78 & 93.72 \\
$15 \mathrm{X}-4,48-50$ & 122.78 & 94.09 \\
$15 \mathrm{X}-6,48-50$ & 125.78 & 94.71 \\
$16 \mathrm{X}-2,47-49$ & 128.38 & 95.62 \\
$17 \mathrm{X}-2,47-49$ & 139.17 & 94.45 \\
$17 \mathrm{X}-4,48-50$ & 142.18 & 95.47 \\
$18 \mathrm{X}-2,46-48$ & 148.76 & 87.90 \\
$18 \mathrm{X}-4,46-48$ & 151.76 & 95.23 \\
$19 \mathrm{X}-2,48-50$ & 158.48 & 90.22 \\
$19 \mathrm{X}-4,48-50$ & 161.48 & 95.34 \\
$19 \mathrm{X}-6,48-50$ & 164.48 & 89.57 \\
$20 \mathrm{X}-2,48-50$ & 168.18 & 95.57 \\
$20 \mathrm{X}-4,48-50$ & 171.18 & 90.21 \\
$20 \mathrm{X}-6,48-50$ & 174.18 & 96.35 \\
$21 \mathrm{X}-2,48-50$ & 177.72 & 92.57 \\
$21 \mathrm{X}-4,44-46$ & 179.84 & 97.94 \\
$22 \mathrm{X}-2,48-50$ & 187.38 & 94.93 \\
$22 \mathrm{X}-4,48-50$ & 190.38 & 86.95 \\
$23 \mathrm{X}-1,40-42$ & 195.40 & 95.64 \\
$24 \mathrm{X}-1,48-50$ & 205.08 & 97.20 \\
$24 \mathrm{X}-3,48-50$ & 208.08 & 94.63
\end{tabular}

$119-738 \mathrm{C}$ -

\begin{tabular}{lll} 
4R-1, 20-22 & 216.10 & 95.01 \\
4R-2, 4-6 & 217.44 & 94.95 \\
5R-CC, 0-1 & 227.88 & 95.05 \\
6R-1, 48-50 & 235.68 & 94.37 \\
7R-1, 72-74 & 245.52 & 90.98 \\
$7 \mathrm{R}-3,19-20$ & 247.99 & 89.47 \\
$8 \mathrm{R}-1,48-50$ & 254.88 & 96.05 \\
9R-1, 47-50 & 264.57 & 88.59 \\
10R-3, 74-76 & 277.54 & 93.39 \\
11R-1, 54-56 & 283.94 & 90.79 \\
11R-2, 54-56 & 285.44 & 69.24 \\
16R-2, 48-50 & 333.58 & 91.45 \\
16R-6, 48-50 & 339.58 & 93.10 \\
17R-2, 48-50 & 343.19 & 93.24 \\
17R-4, 48-50 & 346.07 & 94.38 \\
17R-6, 48-50 & 348.94 & 94.93 \\
18R-1, 48-50 & 351.38 & 95.54 \\
18R-4, 48-50 & 355.88 & 95.50 \\
19R-1, 45-47 & 360.95 & 87.25 \\
19R-3, 47-49 & 363.97 & 92.82 \\
20R-3, 30-32 & 373.50 & 92.47 \\
20R-5, 30-32 & 376.50 & 85.58 \\
21R-CC, 8-10 & 380.67 & 94.20 \\
22R-1, 48-50 & 390.08 & 96.54 \\
22R-4, 48-50 & 394.58 & 96.63 \\
23R-1, 28-30 & 399.48 & 93.36 \\
23R-3, 36-38 & 402.56 & 88.03 \\
24R-1, 26-28 & 409.16 & 84.56 \\
24R-CC, 1-3 & 413.26 & 88.98 \\
25R-2, 48-50 & 420.58 & 89.19 \\
25R-4, 47-49 & 423.57 & 87.05 \\
26R-1, 48-50 & 428.68 & 83.61 \\
26R-3, 48-50 & 431.68 & 84.15 \\
27R-2, 47-50 & 439.87 & 90.40 \\
27R-4, 52-54 & 442.92 & 92.25 \\
27R-5, 50-52 & 444.40 & 86.77 \\
28R-4, 23-25 & 452.33 & 87.27 \\
29R-1, 43-45 & 457.63 & 94.75 \\
29R-3, 48-49 & 460.68 & 77.58 \\
30R-1, 93-95 & 467.53 & 94.04 \\
30R-3, 6-7 & 469.66 & 93.10 \\
31R-1, 50-52 & 476.80 & 88.45 \\
31R-2, 48-50 & 478.28 & 82.72 \\
31R-3, 11-13 & 479.41 & 43.51 \\
& & \\
\hline
\end{tabular}


APPENDIX TABLE 3.

Grain-Size Distribution of the Nonbiogenic Sediment Components at Holes 738B, 738C, and 744A (carbonate-free, opal-free)

\begin{tabular}{|c|c|c|c|c|c|c|}
\hline \multirow{2}{*}{$\begin{array}{l}\text { Core, section, } \\
\text { interval }(\mathrm{cm})\end{array}$} & \multirow{2}{*}{$\begin{array}{l}\text { Depth } \\
\text { (mbsf) }\end{array}$} & \multicolumn{2}{|c|}{$>2 \mathrm{~mm}$} & \multirow{2}{*}{$\begin{array}{c}63 \mu \mathrm{m}-2 \mathrm{~mm} \\
(\%)\end{array}$} & \multirow{2}{*}{$\begin{array}{c}2-63 \mu \mathrm{m} \\
(\%)\end{array}$} & \multirow{2}{*}{$\begin{array}{c}<2 \mu \mathrm{m} \\
(\%)\end{array}$} \\
\hline & & (n) & (g) & & & \\
\hline \multicolumn{7}{|l|}{ 119-738B- } \\
\hline $3 \mathrm{H}-1,125-129$ & 14.75 & 11 & 0.28 & 27.69 & 32.67 & 39.64 \\
\hline $3 \mathrm{H}-5,48-52$ & 19.98 & 0 & 0.00 & 1.07 & 20.27 & 78.66 \\
\hline $4 \mathrm{H}-1,110-114$ & 24.06 & 0 & 0.00 & 0.18 & 7.01 & 92.82 \\
\hline $4 \mathrm{H}-3,48-52$ & 26.35 & 0 & 0.00 & 0.54 & 5.91 & 93.56 \\
\hline $4 \mathrm{H}-5,78-82$ & 29.52 & 0 & 0.00 & 0.23 & 6.00 & 93.77 \\
\hline $4 \mathrm{H}-7,30-34$ & 31.94 & 0 & 0.00 & 0.00 & 7.29 & 92.71 \\
\hline $5 \mathrm{H}-1,100-104$ & 33.46 & 0 & 0.00 & 0.31 & 4.20 & 95.48 \\
\hline $5 \mathrm{H}-3,48-52$ & 35.85 & 0 & 0.00 & 0.25 & 6.12 & 93.63 \\
\hline $5 \mathrm{H}-5,48-52$ & 38.73 & 0 & 0.00 & 0.29 & 7.43 & 92.29 \\
\hline $5 \mathrm{H}-7,30-34$ & 41.44 & 0 & 0.00 & 0.45 & 6.66 & 92.89 \\
\hline $6 \mathrm{H}-1,48-52$ & 42.48 & 0 & 0.00 & 0.03 & 9.80 & 90.17 \\
\hline $6 \mathrm{H}-3,48-52$ & 45.48 & 0 & 0.00 & 0.19 & 7.87 & 91.94 \\
\hline $6 \mathrm{H}-5,48-52$ & 48.48 & 0 & 0.00 & 0.15 & 6.94 & 92.91 \\
\hline $7 \mathrm{H}-1,100-104$ & 52.47 & 0 & 0.00 & 0.12 & 6.97 & 92.91 \\
\hline $7 \mathrm{H}-3,48-52$ & 54.85 & 0 & 0.00 & 0.00 & 4.43 & 95.57 \\
\hline $7 \mathrm{H}-5,48-52$ & 57.79 & 0 & 0.00 & 0.00 & 9.56 & 90.44 \\
\hline $8 \mathrm{H}-3,48-52$ & 64.35 & 0 & 0.00 & 0.64 & 13.49 & 85.87 \\
\hline $8 \mathrm{H}-5,48-52$ & 67.29 & 0 & 0.00 & 0.03 & 15.32 & 84.65 \\
\hline $8 \mathrm{H}-7,30-34$ & 70.03 & 0 & 0.00 & 0.18 & 9.52 & 90.30 \\
\hline $9 \mathrm{H}-1,80-84$ & 71.30 & 0 & 0.00 & 0.00 & 27.26 & 72.74 \\
\hline $9 \mathrm{H}-3,48-52$ & 73.98 & 0 & 0.00 & 0.00 & 19.69 & 80.31 \\
\hline $10 \mathrm{H}-1,48-52$ & 80.48 & 0 & 0.00 & 0.21 & 13.18 & 86.61 \\
\hline $10 \mathrm{H}-3,48-52$ & 83.48 & 0 & 0.00 & 0.33 & 26.38 & 73.29 \\
\hline $11 \mathrm{H}-1,48-52$ & 85.48 & 1 & 0.02 & 0.11 & 19.52 & 80.37 \\
\hline $11 \mathrm{H}-3,48-52$ & 88.48 & 0 & 0.00 & 0.00 & 25.70 & 74.30 \\
\hline $11 \mathrm{H}-5,48-52$ & 91.48 & 0 & 0.00 & 0.10 & 5.43 & 94.47 \\
\hline $12 \mathrm{H}-1,48-52$ & 94.98 & 0 & 0.00 & 0.00 & 3.21 & 96.79 \\
\hline $12 \mathrm{H}-3,48-52$ & 97.98 & 0 & 0.00 & 0.00 & 9.89 & 90.11 \\
\hline $12 \mathrm{H}-5,48-52$ & 100.98 & 0 & 0.00 & 0.00 & 2.75 & 97.25 \\
\hline $13 \mathrm{H}-1,48-52$ & 104.47 & 1 & 0.02 & 8.81 & 6.38 & 84.81 \\
\hline $13 \mathrm{H}-3,48-52$ & 107.17 & 0 & 0.00 & 0.06 & 5.95 & 93.99 \\
\hline $14 X-1,48-52$ & 108.68 & 0 & 0.00 & 1.33 & 10.81 & 87.86 \\
\hline $14 X-3,48-52$ & 111.68 & 0 & 0.00 & 0.14 & 10.53 & 89.33 \\
\hline $15 X-1,72-76$ & 118.52 & 0 & 0.00 & 0.00 & 6.12 & 93.88 \\
\hline $15 X-3,48-52$ & 121.28 & 0 & 0.00 & 1.20 & 3.07 & 95.73 \\
\hline $15 X-5,48-52$ & 124.28 & 0 & 0.00 & 0.04 & 13.19 & 86.77 \\
\hline $16 \mathrm{X}-1,16-20$ & 127.66 & 0 & 0.00 & 0.00 & 20.09 & 79.91 \\
\hline $16 \mathrm{X}-3,30-34$ & 130.80 & 0 & 0.00 & 1.59 & 8.34 & 90.07 \\
\hline $17 X-1,60-64$ & 137.80 & 0 & 0.00 & 0.20 & 5.23 & 94.57 \\
\hline $17 X-3,48-52$ & 140.68 & 0 & 0.00 & 0.21 & 12.95 & 86.84 \\
\hline $18 \mathrm{X}-1,48-52$ & 147.28 & 0 & 0.00 & 0.11 & 13.66 & 86.23 \\
\hline $18 X-3,48-52$ & 150.28 & 0 & 0.00 & 0.16 & 14.94 & 84.94 \\
\hline $18 X-5,48-52$ & 153.28 & 0 & 0.00 & 0.00 & 11.55 & 88.45 \\
\hline $19 X-1,42-46$ & 156.92 & 0 & 0.00 & 0.00 & 19.96 & 80.04 \\
\hline $19 X-3,46-50$ & 159.96 & 0 & 0.00 & 0.14 & 14.90 & 84.97 \\
\hline $19 X-5,48-52$ & 162.98 & 0 & 0.00 & 0.00 & 20.32 & 79.68 \\
\hline $20 \mathrm{X}-1,48-52$ & 166.68 & 0 & 0.00 & 0.17 & 25.06 & 74.77 \\
\hline $20 \mathrm{X}-3,48-52$ & 169.68 & 0 & 0.00 & 0.00 & 28.09 & 71.91 \\
\hline $20 \mathrm{X}-5,48-52$ & 172.68 & 0 & 0.00 & 0.00 & 6.80 & 93.20 \\
\hline $21 X-2,48-52$ & 176.28 & 0 & 0.00 & 0.31 & 21.75 & 77.94 \\
\hline $21 X-3,48-52$ & 179.26 & 0 & 0.00 & 0.05 & 18.40 & 81.55 \\
\hline $22 \mathrm{X}-1,48-52$ & 185.88 & 0 & 0.00 & 0.67 & 2.31 & 97.02 \\
\hline $22 X-3,48-52$ & 188.88 & 0 & 0.00 & 0.00 & 5.27 & 94.73 \\
\hline $24 X-2,48-52$ & 206.58 & 0 & 0.00 & 0.07 & 17.29 & 82.64 \\
\hline \multicolumn{7}{|l|}{ 119-738C- } \\
\hline $4 \mathrm{R}-3,48-52$ & 219.38 & 0 & 0.00 & 0.00 & 10.24 & 89.76 \\
\hline SR-1, 46-50 & 226.06 & 0 & 0.00 & 0.00 & 7.34 & 92.66 \\
\hline 7R-2, 74-76 & 247.04 & 0 & 0.00 & 1.91 & 7.73 & 90.36 \\
\hline $10 \mathrm{R}-2,36-38$ & 275.66 & 0 & 0.00 & 0.13 & 13.43 & 86.44 \\
\hline $11 \mathrm{R}-3,10-12$ & 286.50 & 0 & 0.00 & 4.14 & 13.28 & 82.58 \\
\hline $16 \mathrm{R}-1,48-52$ & 332.08 & 0 & 0.00 & 5.78 & 4.75 & 89.47 \\
\hline $16 R-5,42-44$ & 338.02 & 0 & 0.00 & 1.31 & 5.79 & 92.90 \\
\hline $17 \mathrm{R}-1,58-60$ & 341.86 & 0 & 0.00 & 0.05 & 3.65 & 96.30 \\
\hline $17 \mathrm{R}-3,112-114$ & 345.24 & 0 & 0.00 & 15.05 & 21.75 & 63.20 \\
\hline $17 R-5,56-60$ & 347.58 & 0 & 0.00 & 3.57 & 18.34 & 78.09 \\
\hline $18 \mathrm{R}-1,70-74$ & 351.60 & 3 & 0.03 & 0.04 & 18.85 & 81.11 \\
\hline $18 \mathrm{R}-3,50-54$ & 354.40 & 0 & 0.00 & 0.33 & 9.90 & 89.77 \\
\hline $18 \mathrm{R}-6,48-52$ & 358.88 & 0 & 0.00 & 0.02 & 6.74 & 93.24 \\
\hline $19 \mathrm{R}-2,70-74$ & 362.70 & 0 & 0.00 & 0.00 & 8.53 & 91.47 \\
\hline $20 \mathrm{R}-1,20-24$ & 370.40 & 0 & 0.00 & 2.54 & 7.49 & 89.97 \\
\hline $20 \mathrm{R}-2,50-54$ & 372.20 & 0 & 0.00 & 4.25 & 7.31 & 88.44 \\
\hline $22 \mathrm{R}-2,62-65$ & 391.72 & 0 & 0.00 & 0.12 & 16.53 & 83.35 \\
\hline
\end{tabular}


Appendix Table 3 (continued).

\begin{tabular}{|c|c|c|c|c|c|c|}
\hline \multirow{2}{*}{$\begin{array}{l}\text { Core, section, } \\
\text { interval }(\mathrm{cm})\end{array}$} & \multirow{2}{*}{$\begin{array}{l}\text { Depth } \\
\text { (mbsf) }\end{array}$} & \multicolumn{2}{|c|}{$>2 \mathrm{~mm}$} & \multirow{2}{*}{$\begin{array}{c}63 \mu \mathrm{m}-2 \mathrm{~mm} \\
(\%)\end{array}$} & \multirow{2}{*}{$\begin{array}{c}2-63 \mu \mathrm{m} \\
(\%)\end{array}$} & \multirow{2}{*}{$\begin{array}{c}<2 \mu \mathrm{m} \\
(\%)\end{array}$} \\
\hline & & $(n)$ & (g) & & & \\
\hline \multicolumn{7}{|l|}{ 119-738C-(Cont.) } \\
\hline $22 \mathrm{R}-5,51-53$ & 396.11 & 0 & 0.00 & 0.07 & 16.51 & 83.42 \\
\hline $23 R-2,47-49$ & 401.17 & 0 & 0.00 & 0.11 & 15.76 & 84.14 \\
\hline $24 \mathrm{R}-2,60-62$ & 411.00 & 0 & 0.00 & 0.08 & 6.68 & 93.23 \\
\hline $24 \mathrm{R}-3,50-52$ & 412.40 & 0 & 0.00 & 0.07 & 5.10 & 94.83 \\
\hline $25 \mathrm{R}-1,64-66$ & 419.24 & 0 & 0.00 & 0.16 & 9.11 & 90.73 \\
\hline $25 \mathrm{R}-3,72-74$ & 422.32 & 0 & 0.00 & 0.00 & 20.03 & 79.96 \\
\hline $26 \mathrm{R}-2,54-56$ & 430.24 & 0 & 0.00 & 0.00 & 6.50 & 93.50 \\
\hline $27 \mathrm{R}-1,49-51$ & 438.39 & 0 & 0.00 & 0.11 & 9.90 & 89.99 \\
\hline $27 R-3,49-51$ & 441.39 & 0 & 0.00 & 0.00 & 5.50 & 94.50 \\
\hline $28 \mathrm{R}-1,55-57$ & 448.15 & 0 & 0.00 & 0.00 & 9.27 & 90.73 \\
\hline $28 \mathrm{R}-3,48-50$ & 451.08 & 0 & 0.00 & 0.00 & 8.04 & 91.96 \\
\hline $29 \mathrm{R}-2,48-50$ & 459.18 & 0 & 0.00 & 0.00 & 10.83 & 89.17 \\
\hline $30 \mathrm{R}-2,48-50$ & 468.58 & 0 & 0.00 & 0.01 & 4.42 & 95.57 \\
\hline $119-744 \mathrm{~A}-$ & & & & & & \\
\hline $1 \mathrm{H}-1,49-51$ & 0.49 & 0 & 0.00 & 9.96 & 14.92 & 75.12 \\
\hline $1 \mathrm{H}-3,49-51$ & 3.49 & 0 & 0.00 & 25.14 & 7.25 & 67.61 \\
\hline $2 \mathrm{H}-1,49-51$ & 4.69 & 0 & 0.00 & 17.08 & 9.25 & 73.67 \\
\hline $2 \mathrm{H}-4,49-51$ & 9.19 & 0 & 0.00 & 16.02 & 11.08 & 72.91 \\
\hline $3 \mathrm{H}-1,49-51$ & 14.19 & 8 & 0.42 & 38.53 & 14.23 & 47.24 \\
\hline $3 \mathrm{H}-4,49-51$ & 18.69 & 0 & 0.00 & 18.70 & 13.67 & 67.62 \\
\hline $4 \mathrm{H}-1,44-46$ & 23.64 & 0 & 0.00 & 16.28 & 18.79 & 64.93 \\
\hline $4 \mathrm{H}-2,46-50$ & 25.16 & 0 & 0.00 & 0.42 & 9.40 & 90.18 \\
\hline $4 \mathrm{H}-3,40-44$ & 26.60 & 0 & 0.00 & 4.18 & 17.57 & 78.25 \\
\hline $4 \mathrm{H}-4,45-47$ & 28.15 & 0 & 0.00 & 0.46 & 3.68 & 95.86 \\
\hline $5 \mathrm{H}-1,49-50$ & 33.19 & 0 & 0.00 & 1.24 & 4.85 & 93.91 \\
\hline $5 \mathrm{H}-2,40-44$ & 34.60 & 0 & 0.00 & 0.17 & 12.04 & 87.79 \\
\hline $5 \mathrm{H}-3,47-49$ & 36.17 & 0 & 0.00 & 0.03 & 2.10 & 97.86 \\
\hline $5 \mathrm{H}-4,12-15$ & 37.32 & 0 & 0.00 & 0.13 & 11.92 & 87.94 \\
\hline $6 \mathrm{H}-1,49-51$ & 42.69 & 0 & 0.00 & 0.19 & 3.08 & 96.74 \\
\hline $6 \mathrm{H}-2,60-64$ & 44.30 & 0 & 0.00 & 0.05 & 4.83 & 95.12 \\
\hline $6 \mathrm{H}-3,46-50$ & 45.66 & 0 & 0.00 & 0.09 & 7.47 & 92.44 \\
\hline $6 \mathrm{H}-4,49-51$ & 47.19 & 0 & 0.00 & 1.31 & 0.64 & 98.05 \\
\hline $7 \mathrm{H}-1,81-83$ & 52.51 & 0 & 0.00 & 0.12 & 15.18 & 84.70 \\
\hline $7 \mathrm{H}-2,46-50$ & 53.66 & 0 & 0.00 & 0.02 & 19.29 & 80.69 \\
\hline $7 \mathrm{H}-3,46-50$ & 55.16 & 0 & 0.00 & 0.01 & 24.05 & 75.95 \\
\hline $7 \mathrm{H}-4,49-51$ & 56.69 & 0 & 0.00 & 0.03 & 19.32 & 80.64 \\
\hline $7 \mathrm{H}-6,20-24$ & 59.40 & 0 & 0.00 & 0.04 & 18.50 & 81.46 \\
\hline $8 \mathrm{H}-1,49-51$ & 61.69 & 0 & 0.00 & 0.08 & 13.64 & 86.28 \\
\hline $8 \mathrm{H}-2,46-50$ & 63.16 & 0 & 0.00 & 0.02 & 69.25 & 30.73 \\
\hline $8 \mathrm{H}-3,46-50$ & 64.66 & 0 & 0.00 & 0.31 & 91.52 & 8.17 \\
\hline $8 \mathrm{H}-4,49-51$ & 66.19 & 0 & 0.00 & 0.11 & 13.28 & 86.61 \\
\hline $9 \mathrm{H}-1,49-51$ & 71.19 & 0 & 0.00 & 0.47 & 3.18 & 96.35 \\
\hline $10 \mathrm{H}-1,44-46$ & 80.62 & 0 & 0.00 & 0.39 & 11.11 & 88.50 \\
\hline $10 \mathrm{H}-2,46-50$ & 81.60 & 0 & 0.00 & 0.03 & 10.66 & 89.31 \\
\hline $10 \mathrm{H}-4,44-46$ & 84.95 & 0 & 0.00 & 0.02 & 8.63 & 91.35 \\
\hline $10 \mathrm{H}-5,46-50$ & 86.41 & 0 & 0.00 & 0.02 & 8.24 & 91.73 \\
\hline $10 \mathrm{H}-7,48-52$ & 89.32 & 0 & 0.00 & 0.08 & 13.29 & 86.63 \\
\hline $11 \mathrm{H}-1,49-51$ & 90.19 & 0 & 0.00 & 0.20 & 7.03 & 92.76 \\
\hline $11 \mathrm{H}-3,48-52$ & 93.18 & 0 & 0.00 & 0.28 & 20.46 & 79.27 \\
\hline $11 \mathrm{H}-4,49-51$ & 94.69 & 0 & 0.00 & 0.10 & 13.67 & 86.23 \\
\hline $11 \mathrm{H}-6,48-52$ & 97.68 & 0 & 0.00 & 0.16 & 20.55 & 79.28 \\
\hline $12 \mathrm{H}-1,49-51$ & 99.67 & 0 & 0.00 & 0.32 & 16.20 & 83.48 \\
\hline $12 \mathrm{H}-3,48-52$ & 102.55 & 0 & 0.00 & 0.02 & 18.26 & 81.72 \\
\hline $12 \mathrm{H}-4,49-51$ & 104.00 & 0 & 0.00 & 0.44 & 17.18 & 82.38 \\
\hline $12 \mathrm{H}-6,46-50$ & 106.85 & 0 & 0.00 & 0.04 & 16.02 & 83.94 \\
\hline $13 \mathrm{H}-1,49-51$ & 109.19 & 0 & 0.00 & 0.31 & 13.13 & 86.57 \\
\hline $13 \mathrm{H}-3,48-52$ & 112.15 & 0 & 0.00 & 0.09 & 14.54 & 85.38 \\
\hline $13 \mathrm{H}-4,49-51$ & 113.64 & 0 & 0.00 & 0.27 & 15.91 & 83.82 \\
\hline $13 \mathrm{H}-6,46-50$ & 116.58 & 0 & 0.00 & 0.02 & 12.77 & 87.21 \\
\hline $14 \mathrm{H}-1,49-51$ & 118.69 & 0 & 0.00 & 0.15 & 18.73 & 81.12 \\
\hline $14 \mathrm{H}-3,46-50$ & 121.66 & 0 & 0.00 & 0.07 & 7.95 & 91.97 \\
\hline $14 \mathrm{H}-4,49-51$ & 123.19 & 0 & 0.00 & 0.26 & 10.01 & 89.73 \\
\hline $14 \mathrm{H}-6,46-50$ & 126.16 & 0 & 0.00 & 0.15 & 18.25 & 81.59 \\
\hline $15 \mathrm{H}-1,49-51$ & 128.18 & 0 & 0.00 & 0.49 & 10.70 & 88.82 \\
\hline $15 \mathrm{H}-3,46-50$ & 131.06 & 0 & 0.00 & 0.14 & 13.16 & 86.70 \\
\hline $15 \mathrm{H}-4,49-51$ & 132.54 & 0 & 0.00 & 0.59 & 6.95 & 92.46 \\
\hline $15 \mathrm{H}-6,46-50$ & 135.43 & 0 & 0.00 & 0.14 & 9.41 & 90.44 \\
\hline $16 \mathrm{H}-1,49-51$ & 137.67 & 0 & 0.00 & 0.84 & 9.31 & 89.85 \\
\hline $16 \mathrm{H}-2,46-50$ & 139.09 & 0 & 0.00 & 0.21 & 9.01 & 90.79 \\
\hline $16 \mathrm{H}-4,49-51$ & 142.00 & 0 & 0.00 & 1.45 & 12.98 & 85.57 \\
\hline $16 \mathrm{H}-5,46-50$ & 143.41 & 0 & 0.00 & 0.05 & 6.52 & 93.44 \\
\hline $16 \mathrm{H}-7,47-49$ & 146.31 & 3 & 0.14 & 37.81 & 16.78 & 45.42 \\
\hline $17 \mathrm{H}-1,12-14$ & 146.82 & 0 & 0.00 & 1.46 & 4.08 & 94.46 \\
\hline $17 \mathrm{H}-\mathrm{CC}, 12-14$ & 147.29 & 5 & 0.26 & 5.74 & 5.81 & 88.45 \\
\hline
\end{tabular}


Appendix Table 3 (continued).

\begin{tabular}{|c|c|c|c|c|c|c|}
\hline \multirow{2}{*}{$\begin{array}{l}\text { Core, section, } \\
\text { interval }(\mathrm{cm})\end{array}$} & \multirow{2}{*}{$\begin{array}{l}\text { Depth } \\
\text { (mbsf) }\end{array}$} & \multicolumn{2}{|c|}{$>2 \mathrm{~mm}$} & \multirow{2}{*}{$\underset{(\%)}{63 \mu \mathrm{m}-2 \mathrm{~mm}}$} & \multirow{2}{*}{$\begin{array}{c}2-63 \mu \mathrm{m} \\
(\%)\end{array}$} & \multirow{2}{*}{$\begin{array}{c}<2 \mu \mathrm{m} \\
(\%)\end{array}$} \\
\hline & & (n) & (g) & & & \\
\hline \multicolumn{7}{|l|}{ 119-744A-(Cont.) } \\
\hline $18 \mathrm{H}-1,49-51$ & 148.08 & 0 & 0.00 & 0.88 & 4.80 & 94.32 \\
\hline $18 \mathrm{H}-2,46-50$ & 149.52 & 0 & 0.00 & 0.40 & 9.27 & 90.33 \\
\hline $18 \mathrm{H}-4,49-51$ & 152.49 & 0 & 0.00 & 0.17 & 4.62 & 95.21 \\
\hline $18 \mathrm{H}-6,46-50$ & 155.40 & 0 & 0.00 & 0.03 & 6.01 & 93.97 \\
\hline $19 \mathrm{H}-1,49-51$ & 157.59 & 0 & 0.00 & 0.58 & 0.62 & 98.81 \\
\hline $19 \mathrm{H}-2,46-50$ & 159.06 & 0 & 0.00 & 0.04 & 4.16 & 95.80 \\
\hline $19 \mathrm{H}-4,49-51$ & 162.09 & 0 & 0.00 & 0.30 & 1.02 & 98.68 \\
\hline $19 \mathrm{H}-6,46-50$ & 165.06 & 0 & 0.00 & 0.21 & 7.26 & 92.52 \\
\hline $20 \mathrm{H}-1,49-51$ & 167.00 & 1 & 0.36 & 0.19 & 9.00 & 90.81 \\
\hline $20 \mathrm{H}-2,26-30$ & 168.29 & 2 & 0.04 & 1.71 & 2.70 & 95.59 \\
\hline $20 \mathrm{H}-2,130-134$ & 169.29 & 0 & 0.00 & 0.03 & 2.69 & 97.27 \\
\hline $20 \mathrm{H}-3,49-51$ & 169.96 & 0 & 0.00 & 0.22 & 1.11 & 98.66 \\
\hline $20 \mathrm{H}-5,46-50$ & 172.81 & 0 & 0.00 & 0.02 & 2.99 & 96.98 \\
\hline $20 \mathrm{H}-6,49-51$ & 174.28 & 0 & 0.00 & 0.58 & 1.55 & 97.87 \\
\hline $20 \mathrm{H}-7,46-50$ & 175.70 & 0 & 0.00 & 0.05 & 7.84 & 92.11 \\
\hline
\end{tabular}

APPENDIX TABLE 4.

Amount of Terrigenous Clay (nonbiogenic, $<2 \mu \mathrm{m}$ ) and Relative Percentage of the Clay Minerals Smectite, Illite, Chlorite, and Kaolinite at Holes 738B, $738 \mathrm{C}$, and $744 \mathrm{~A}$

\begin{tabular}{|c|c|c|c|c|c|c|}
\hline $\begin{array}{l}\text { Core, section, } \\
\text { interval }(\mathrm{cm})\end{array}$ & $\begin{array}{l}\text { Depth } \\
\text { (mbsf) }\end{array}$ & $\begin{array}{l}\text { Clay } \\
(\%)\end{array}$ & $\begin{array}{c}\text { Smectite } \\
(\%)\end{array}$ & $\begin{array}{l}\text { Illite } \\
(\%)\end{array}$ & $\begin{array}{c}\text { Chlorite } \\
(\%)\end{array}$ & $\begin{array}{c}\text { Kaolinite } \\
(\%)\end{array}$ \\
\hline \multicolumn{7}{|l|}{ 119-738B- } \\
\hline $3 \mathrm{H}-1,125-129$ & 14.75 & 24.19 & 31 & 51 & 10 & 8 \\
\hline $3 \mathrm{H}-5,48-52$ & 19.98 & 5.08 & 51 & 31 & 11 & 6 \\
\hline $4 \mathrm{H}-1,110-114$ & 24.06 & 4.84 & 37 & 34 & 24 & 5 \\
\hline $4 \mathrm{H}-3,48-52$ & 26.35 & 3.69 & 65 & 13 & 16 & 7 \\
\hline $4 \mathrm{H}-5,78-82$ & 29.52 & 4.28 & 78 & 10 & 3 & 9 \\
\hline $4 \mathrm{H}-7,30-34$ & 31.94 & 4.54 & 97 & 1 & 0 & 1 \\
\hline $5 \mathrm{H}-1,100-104$ & 33.46 & 6.03 & 70 & 8 & 13 & 9 \\
\hline $5 \mathrm{H}-3,48-52$ & 35.85 & 4.02 & 59 & 15 & 14 & 13 \\
\hline $5 \mathrm{H}-5,48-52$ & 38.73 & 3.87 & 77 & 11 & 8 & 5 \\
\hline $5 \mathrm{H}-7,30-34$ & 41.44 & 4.87 & 88 & 8 & 1 & 3 \\
\hline $6 \mathrm{H}-1,48-52$ & 42.48 & 5.70 & 93 & 3 & 1 & 2 \\
\hline $6 \mathrm{H}-3,48-52$ & 45.48 & 6.18 & 93 & 5 & 1 & 1 \\
\hline $6 \mathrm{H}-5,48-52$ & 48.48 & 1.30 & 88 & 10 & 0 & 2 \\
\hline $7 \mathrm{H}-1,100-104$ & 52.47 & 4.58 & 92 & 6 & 1 & 1 \\
\hline $7 \mathrm{H}-3,48-52$ & 54.85 & 5.55 & 96 & 2 & 1 & 1 \\
\hline $7 \mathrm{H}-5,48-52$ & 57.79 & 6.56 & 92 & 7 & 2 & 0 \\
\hline $8 \mathrm{H}-3,48-52$ & 64.35 & 5.59 & 90 & 7 & 1 & 2 \\
\hline $8 \mathrm{H}-5,48-52$ & 67.29 & 4.91 & 88 & 8 & 2 & 2 \\
\hline $8 \mathrm{H}-7,30-34$ & 70.03 & 3.53 & 90 & 8 & 1 & 2 \\
\hline $9 \mathrm{H}-1,80-84$ & 71.30 & 4.05 & 91 & 7 & 1 & 1 \\
\hline $9 \mathrm{H}-3,48-52$ & 73.98 & 4.34 & & & & \\
\hline $10 \mathrm{H}-1,48-52$ & 80.48 & 4.87 & 92 & 4 & 2 & 2 \\
\hline $10 \mathrm{H}-3,48-52$ & 83.48 & 3.00 & 90 & 8 & 1 & 1 \\
\hline $11 \mathrm{H}-1,48-52$ & 85.48 & 1.62 & 91 & 6 & 1 & 2 \\
\hline $11 \mathrm{H}-3,48-52$ & 88.48 & & 89 & 6 & 3 & 2 \\
\hline $11 \mathrm{H}-5,48-52$ & 91.48 & 5.55 & 89 & 7 & 2 & 2 \\
\hline $12 \mathrm{H}-1,48-52$ & 94.98 & 5.43 & 91 & 7 & 1 & 0 \\
\hline $12 \mathrm{H}-3,48-52$ & 97.98 & 4.33 & 91 & 7 & 2 & 1 \\
\hline $12 \mathrm{H}-5,48-52$ & 100.98 & 4.17 & 96 & 3 & 1 & 1 \\
\hline $13 \mathrm{H}-1,48-52$ & 104.47 & 4.04 & 79 & 18 & 2 & 1 \\
\hline $13 \mathrm{H}-3,48-52$ & 107.17 & 3.95 & 87 & 10 & 1 & 2 \\
\hline $14 X-1,48-52$ & 108.68 & 6.16 & 87 & 8 & 4 & 1 \\
\hline $14 X-3,48-52$ & 111.68 & 5.49 & 95 & 3 & 0 & 1 \\
\hline $15 X-1,72-76$ & 118.52 & 1.23 & 97 & 1 & 0 & 2 \\
\hline $15 X-3,48-52$ & 121.28 & 4.33 & 81 & 14 & 4 & 2 \\
\hline $15 X-5,48-52$ & 124.28 & 4.70 & 91 & 6 & 1 & 2 \\
\hline $16 \mathrm{X}-1,16-20$ & 127.66 & 2.68 & 88 & 10 & 1 & 2 \\
\hline $16 \mathrm{X}-3,30-34$ & 130.80 & 1.12 & 94 & 4 & 1 & 1 \\
\hline $17 X-1,60-64$ & 137.80 & 4.23 & 85 & 2 & 7 & 6 \\
\hline $17 X-3,48-52$ & 140.68 & 4.33 & 80 & 3 & 9 & 7 \\
\hline $18 \mathrm{X}-1,48-52$ & 147.28 & 2.67 & 88 & 2 & 5 & 5 \\
\hline $18 X-3,48-52$ & 150.28 & 3.32 & 82 & 6 & 7 & 6 \\
\hline $18 X-5,48-52$ & 153.28 & 3.02 & 92 & 6 & 1 & 1 \\
\hline $19 X-1,42-46$ & 156.92 & 1.47 & 90 & 8 & 1 & 1 \\
\hline $19 X-3,46-50$ & 159.96 & 3.07 & 95 & 4 & 0 & 1 \\
\hline $19 X-5,48-52$ & 162.98 & 2.77 & 93 & 3 & 2 & 2 \\
\hline $20 \times-1,48-52$ & 166.68 & 2.10 & 94 & 4 & 1 & 2 \\
\hline
\end{tabular}


Appendix Table 4 (continued).

\begin{tabular}{ccccccc}
\hline $\begin{array}{c}\text { Core, section, } \\
\text { interval (cm) }\end{array}$ & $\begin{array}{c}\text { Depth } \\
(\mathrm{mbsf})\end{array}$ & $\begin{array}{c}\text { Clay } \\
(\%)\end{array}$ & $\begin{array}{c}\text { Smectite } \\
(\%)\end{array}$ & $\begin{array}{c}\text { Illite } \\
(\%)\end{array}$ & $\begin{array}{c}\text { Chlorite } \\
(\%)\end{array}$ & $\begin{array}{c}\text { Kaolinite } \\
(\%)\end{array}$ \\
\hline $119-738 \mathrm{~B}-($ Cont.) & & & & & & \\
20X-3, 48-52 & 169.68 & 2.12 & 95 & 2 & 2 & 1 \\
$20 \mathrm{X}-5,48-52$ & 172.68 & 3.24 & 89 & 7 & 3 & 2 \\
$21 \mathrm{X}-2,48-52$ & 176.28 & 2.86 & 97 & 1 & 1 & 1 \\
$21 \mathrm{X}-3,48-52$ & 179.26 & 3.14 & 94 & 3 & 1 & 2 \\
$22 \mathrm{X}-1,48-52$ & 185.88 & 3.71 & 92 & 6 & 1 & 1 \\
$22 \mathrm{X}-3,48-52$ & 188.88 & 4.19 & 95 & 5 & 1 & 0 \\
$24 \mathrm{X}-2,48-52$ & 206.58 & 3.12 & 93 & 3 & 2 & 1
\end{tabular}

119-738C.

$\begin{array}{lrr}\text { 4R-3, 48-52 } & 219.38 & 5.57 \\ \text { 5R-1, 46-50 } & 226.06 & 4.56 \\ \text { 7R-2, 74-76 } & 247.04 & 4.78 \\ 10 \mathrm{R}-2,36-38 & 275.66 & 3.36 \\ 11 \mathrm{R}-3,10-12 & 286.50 & 4.48 \\ 16 \mathrm{R}-1,48-52 & 332.08 & 5.51 \\ 16 \mathrm{R}-5,42-44 & 338.02 & 6.64 \\ 17 \mathrm{R}-1,58-60 & 341.86 & 4.57 \\ 17 \mathrm{R}-3,112-114 & 345.24 & 2.92 \\ 17 \mathrm{R}-5,56-60 & 347.58 & 2.36 \\ 18 \mathrm{R}-1,70-74 & 351.60 & 1.83 \\ 18 \mathrm{R}-3,50-54 & 354.40 & 3.03 \\ 18 \mathrm{R}-6,48-52 & 358.88 & 0.51 \\ \text { 19R-2, 70-74 } & 362.70 & 1.04 \\ \text { 20R-1, 20-24 } & 370.40 & 2.08 \\ \text { 20R-2, 50-54 } & 372.20 & 2.68 \\ \text { 20R-5, 89-90 } & 377.09 & \\ \text { 22R-2, 62-65 } & 391.72 & 3.82 \\ \text { 22R-5, 51-53 } & 396.11 & 3.72 \\ \text { 23R-2, 47-49 } & 401.17 & 6.70 \\ \text { 24R-2, 60-62 } & 411.00 & 6.07 \\ \text { 24R-3, 50-52 } & 412.40 & 10.74 \\ \text { 25R-1, 64-66 } & 419.24 & 12.38 \\ \text { 25R-3, 72-74 } & 422.32 & 9.16 \\ \text { 26R-2, 54-56 } & 430.24 & 10.23 \\ \text { 27R-1, 49-51 } & 438.39 & 8.69 \\ \text { 27R-3, 49-51 } & 441.39 & 7.75 \\ \text { 28R-1, 55-57 } & 448.15 & 5.93 \\ \text { 28R-3, 48-50 } & 451.08 & 11.84 \\ \text { 29R-2, 48-50 } & 459.18 & 11.19 \\ \text { 30R-2, 48-50 } & 468.58 & 11.82 \\ & & \end{array}$

$\begin{array}{llll}97 & 2 & 1 & 0 \\ 99 & 1 & 0 & 0 \\ 92 & 7 & 0 & 0 \\ 94 & 4 & 1 & 1\end{array}$

9-744A

$1 \mathrm{H}-1,49-51$

1H-3, 49-5

2H-1, 49-51

$2 \mathrm{H}-4,49-51$

$3 \mathrm{H}-1,49-51$

$3 \mathrm{H}-4,49-51$

$4 \mathrm{H}-1,44-46$

$4 \mathrm{H}-2,46-50$

$4 \mathrm{H}-3,40-44$

$4 \mathrm{H}-4,45-47$

$5 \mathrm{H}-1,49-50$

$5 \mathrm{H}-2,40-44$

5H-3, 47-49

$5 \mathrm{H}-4,12-15$

$6 \mathrm{H}-1,49-51$

$6 \mathrm{H}-2,60-64$

$6 \mathrm{H}-4,49-51$

7H-1, 81-83

7H-2, 46-50

7H-3, 46-50

$7 \mathrm{H}-4,49-5$

7H-6, 20-24

$8 \mathrm{H}-1,49-51$

$8 \mathrm{H}-2,46-50$

$8 \mathrm{H}-3,46-50$

$8 \mathrm{H}-4,49-51$

9H-1, 49-51

$10 \mathrm{H}-1,44-46$

$10 \mathrm{H}-2,46-50$

$10 \mathrm{H}-4,44-46$

$10 \mathrm{H}-5,46-50$

$10 \mathrm{H}-7,48-52$

$\begin{array}{ll}0.49 & 13.91\end{array}$

$46 \quad 32$

$3.49 \quad 8.11$

$4.69 \quad 7.77$

$9.19 \quad 15.03$

$14.19 \quad 20.83$

18.6926 .00

$23.64 \quad 11.04$

$25.16 \quad 3.00$

$26.60 \quad 2.11$

$28.15 \quad 7.27$

$33.19 \quad 3.31$

$34.60 \quad 4.15$

$36.17 \quad 9.50$

$37.32 \quad 4.37$

$42.69 \quad 2.15$

$44.30 \quad 2.76$

$47.19 \quad 5.10$

$52.51 \quad 14.00$

$53.66 \quad 8.96$

$55.16 \quad 8.58$

$56.69 \quad 9.69$

$59.40 \quad 3.96$

$\begin{array}{ll}61.69 & 7.83\end{array}$

$63.16 \quad 2.09$

$\begin{array}{ll}64.66 & 0.69\end{array}$

$66.19 \quad 8.81$

$71.19 \quad 2.52$

$80.62 \quad 8.85$

$81.60 \quad 3.01$

$84.95 \quad 6.17$

$86.41 \quad 3.23$

$89.32 \quad 5.38$

$11 \mathrm{H}-1,49-51$

$90.19 \quad 6.33$

$\begin{array}{rrrr}46 & 32 & 14 & 8 \\ 31 & 50 & 15 & 4 \\ 22 & 50 & 6 & 23 \\ 39 & 41 & 11 & 9 \\ 35 & 48 & 15 & 2 \\ 48 & 36 & 13 & 4 \\ 38 & 45 & 8 & 9 \\ 47 & 37 & 9 & 7 \\ 59 & 19 & 15 & 7 \\ 25 & 61 & 10 & 4 \\ 22 & 62 & 7 & 10 \\ 54 & 34 & 11 & 1 \\ 49 & 32 & 11 & 8 \\ 44 & 46 & 7 & 3 \\ 14 & 71 & 14 & 1 \\ 38 & 47 & 10 & 6 \\ 38 & 45 & 13 & 3 \\ 44 & 42 & 5 & 9 \\ 45 & 39 & 3 & 13 \\ 39 & 43 & 14 & 4 \\ 37 & 53 & 8 & 2 \\ 43 & 40 & 9 & 8 \\ 43 & 48 & 8 & 2 \\ 42 & 42 & 15 & 1 \\ 47 & 38 & 9 & 6 \\ 41 & 53 & 4 & 2 \\ 13 & 78 & 7 & 1 \\ 34 & 52 & 12 & 1 \\ 68 & 23 & 6 & 3 \\ 36 & 50 & 8 & 6 \\ 57 & 36 & 2 & 5 \\ 61 & 26 & 2 & 11 \\ 45 & 46 & 7 & 2\end{array}$


Appendix Table 4 (continued).

\begin{tabular}{|c|c|c|c|c|c|c|}
\hline $\begin{array}{l}\text { Core, section, } \\
\text { interval }(\mathrm{cm})\end{array}$ & $\begin{array}{l}\text { Depth } \\
\text { (mbsf) }\end{array}$ & $\begin{array}{l}\text { Clay } \\
(\%)\end{array}$ & $\begin{array}{l}\text { Smectite } \\
(\%)\end{array}$ & $\begin{array}{l}\text { Illite } \\
(\%)\end{array}$ & $\begin{array}{c}\text { Chlorite } \\
(\%)\end{array}$ & $\begin{array}{c}\text { Kaolinite } \\
(\%)\end{array}$ \\
\hline \multicolumn{7}{|l|}{ 119-744A-(Cont.) } \\
\hline $11 \mathrm{H}-3,48-52$ & 93.18 & 4.42 & 67 & 17 & 9 & 8 \\
\hline $11 \mathrm{H}-4,49-51$ & 94.69 & 5.00 & 39 & 51 & 6 & 4 \\
\hline $11 \mathrm{H}-6,48-52$ & 97.68 & 9.21 & 46 & 38 & 14 & 2 \\
\hline $12 \mathrm{H}-1,49-51$ & 99.67 & 8.67 & 33 & 51 & 12 & 4 \\
\hline $12 \mathrm{H}-3,48-52$ & 102.55 & 4.09 & 31 & 52 & 2 & 15 \\
\hline $12 \mathrm{H}-4,49-51$ & 104.00 & 5.25 & 27 & 59 & 14 & 0 \\
\hline $12 \mathrm{H}-6,46-50$ & 106.85 & 7.16 & 52 & 27 & 7 & 14 \\
\hline $13 \mathrm{H}-1,49-51$ & 109.19 & 4.93 & 31 & 56 & 9 & 5 \\
\hline $13 \mathrm{H}-3,48-52$ & 112.15 & 6.66 & 44 & 40 & 8 & 9 \\
\hline $13 \mathrm{H}-4,49-51$ & 113.64 & 5.95 & 44 & 42 & 10 & 4 \\
\hline $13 \mathrm{H}-6,46-50$ & 116.58 & 5.42 & 51 & 40 & 6 & 3 \\
\hline $14 \mathrm{H}-1,49-51$ & 118.69 & 6.86 & 32 & 44 & 14 & 10 \\
\hline $14 \mathrm{H}-3,46-50$ & 121.66 & 3.17 & 41 & 38 & 11 & 11 \\
\hline $14 \mathrm{H}-4,49-51$ & 123.19 & 5.52 & 43 & 41 & 11 & 6 \\
\hline $14 \mathrm{H}-6,46-50$ & 126.16 & 6.10 & 24 & 64 & 8 & 3 \\
\hline $15 \mathrm{H}-1,49-51$ & 128.18 & 6.03 & 40 & 46 & 10 & 4 \\
\hline $15 \mathrm{H}-3,46-50$ & 131.06 & 6.30 & 47 & 39 & 7 & 7 \\
\hline $15 \mathrm{H}-4,49-51$ & 132.54 & 5.60 & 51 & 40 & 5 & 4 \\
\hline $15 \mathrm{H}-6,46-50$ & 135.43 & 4.54 & 36 & 45 & 10 & 9 \\
\hline $16 \mathrm{H}-1,49-51$ & 137.67 & 4.91 & 47 & 36 & 9 & 8 \\
\hline $16 \mathrm{H}-2,46-50$ & 139.09 & 5.58 & 48 & 44 & 6 & 1 \\
\hline $16 \mathrm{H}-4,49-51$ & 142.00 & 2.43 & 16 & 67 & 14 & 3 \\
\hline $16 \mathrm{H}-5,46-50$ & 143.41 & 7.67 & 25 & 52 & 20 & 2 \\
\hline $16 \mathrm{H}-7,47-49$ & 146.31 & 12.47 & 37 & 21 & 15 & 26 \\
\hline $17 \mathrm{H}-1,12-14$ & 146.82 & 4.46 & 54 & 25 & 11 & 9 \\
\hline $17 \mathrm{H}-\mathrm{CC}, 12-14$ & 147.29 & 4.49 & 46 & 27 & 20 & 7 \\
\hline $18 \mathrm{H}-1,49-51$ & 148.08 & 4.58 & 54 & 26 & 11 & 9 \\
\hline $18 \mathrm{H}-2,46-50$ & 149.52 & 2.82 & 75 & 11 & 10 & 5 \\
\hline $18 \mathrm{H}-4,49-51$ & 152.49 & 3.70 & 55 & 30 & 13 & 2 \\
\hline $18 \mathrm{H}-6,46-50$ & 155.40 & 5.32 & 77 & 7 & 6 & 10 \\
\hline $19 \mathrm{H}-1,49-51$ & 157.59 & 3.36 & 38 & 46 & 11 & 4 \\
\hline $19 \mathrm{H}-2,46-50$ & 159.06 & 3.51 & 74 & 11 & 5 & 10 \\
\hline $19 \mathrm{H}-4,49-51$ & 162.09 & 4.54 & 70 & 20 & 6 & 3 \\
\hline $19 \mathrm{H}-6,46-50$ & 165.06 & 4.33 & 73 & 11 & 12 & 4 \\
\hline $20 \mathrm{H}-1,49-51$ & 167.00 & 6.81 & 86 & 9 & 4 & 2 \\
\hline $20 \mathrm{H}-2,26-30$ & 168.29 & 5.85 & 88 & 8 & 2 & 2 \\
\hline $20 \mathrm{H}-5,46-50$ & 172.81 & 4.35 & 94 & 4 & 2 & 0 \\
\hline $20 \mathrm{H}-6,49-51$ & 174.28 & 5.20 & 84 & 12 & 3 & 2 \\
\hline $20 \mathrm{H}-7,46-50$ & 175.70 & 2.16 & 69 & 26 & 4 & 1 \\
\hline
\end{tabular}

